\title{
Polyoxypregnane Glycosides from the Roots of Marsdenia tenacissima and Their Anti-HIV Activities
}

\author{
Authors \\ Xu Pang ${ }^{1,2 *}$, Li-Ping Kang ${ }^{1,3 *}$, Xiao Mei Fang ${ }^{2 *}$, Yang Zhao ${ }^{1}$, He-Shui \\ $\mathrm{Yu}^{3}$, Li-Feng Han ${ }^{3}$, Hai-Tao Li ${ }^{4}$, Li-Xia Zhang ${ }^{4}$, Bao-Lin Guo ${ }^{5}$, Li-Yan Yu², \\ Bai-Ping $\mathrm{Ma}^{1}$ \\ Affiliations \\ 1 Beijing Institute of Radiation Medicine, Beijing, China \\ 2 Institute of Medicinal Biotechnology, Chinese Academy of Medical \\ Sciences \& Peking Union Medical College, Beijing, China \\ 3 Tianjin University of Traditional Chinese Medicine, Tianjin, China \\ 4 Yunnan Branch of Institute of Medicinal Plant Development, Chi- \\ nese Academy of Medical Sciences \& Peking Union Medical Col- \\ lege, jinghong, China \\ 5 Institute of Medicinal Plant development, Chinese Academy of \\ Medical Sciences \& Peking Union Medical College, Beijing, China
}

\section{Key words}

Marsdenia tenacissima, Asclepiadaceae, polyoxypregnane glycoside, marstenacisside, anti-HIV, antiviral activity

$\begin{array}{ll}\text { received } & \text { July 14, 2015 } \\ \text { revised } & \text { April 17, 2016 } \\ \text { accepted } & \text { April 19, 2016 }\end{array}$

Bibliography

DOI http://dx.doi.org/10.1055/s-0042-108057

Published online June 7, 2016 | Planta Med 2017; 83: 126-134

(c) Georg Thieme Verlag KG Stuttgart · New York I ISSN 0032-0943

\author{
Correspondence \\ Prof. Baiping Ma \\ Beijing Institute of Radiation Medicine \\ No. 27 Tai-ping Road, Haidian District, Beijing 100850, People's \\ Republic of China \\ Tel.: + 861068210077 , Fax: + 861068214653 \\ mabaiping@sina.com
}

\section{Correspondence}

Prof. Lixia Zhang

Yunnan Branch of Institute of Medicinal Plant Development, Chinese Academy of Medical Sciences \& Peking Union Medical College

NO. 138 Xuanwei Street, Jinghong 666100, China

13988194288@163.com

(日)

Supporting information available online at

http://www.thieme-connect.de/products

\section{ABSTRACT}

A continuous phytochemical study on the roots of Marsdenia tenacissima led to the isolation and identification of 13 new polyoxypregnane glycosides named marstenacissides B10-B17 $(1,2,4,7,8,11,12$, and 14) and marstenacissides $A 8-A 12(3,9,10,13$, and 15) in addition to two known polyoxypregnane glycosides marsdenosides $\mathrm{M}$ and $\mathrm{L}$ ( 5 and 6). Their structures were established by spectroscopic techniques and by comparison with the reported data in the literature. Moreover, the anti-HIV activities of these isolates and the previous isolated marstenacissides A1-A7 and B1-B9 were assessed, some of which exhibited slight or negligible effects against HIV-1.

\section{Introduction}

Marsdenia tenacissima (Roxb.) Moon (Asclepiadaceae), a perennial climber recorded in the Flora of China, is extensively distributed in the Yunnan province of China. The roots of this plant are widely used as a traditional herbal medicine of Dai nationality, called "Dai-Bai-Jie" in Chinese, due to its pharmacological functions of clearing heat, expelling miasma, decreasing swelling, alleviating pain, etc. In addition, these roots are also used as the main medicinal materials for preparing a series of preparations [1]. The isolation and structural identification of 16 polyoxypregnanes glycosides (marstenacissides $\mathrm{A} 1-\mathrm{A} 7$ and $\mathrm{B} 1-\mathrm{B} 9$ ) from the roots of M. tenacissima have been reported in our previous paper [2]. A continuous phytochemical study on the roots of $M$. tenacissima led to the further isolation of 13 new chemicals (1-4 and 7-15) and 2 known polyoxypregnane glycosides (5 and 6; • Fig. 1).

\footnotetext{
* These authors contributed equally to this work.
}

The traditional Chinsese medicine with functions of heat clearing and detoxicating is supposed to have specific antiviral activity based on the correlation analysis between this kind of traditional medicine and antiviral drugs [3]. Therefore, the extracts of $M$. auricularis roots were subjected to a preliminary screening of activity against HIV-1, and it was found that the $95 \%$ EtOH extract of $M$. auricularis roots, especially its EtOAc-soluble fraction, exhibited a significant HIV-1 inhibitory effect. In view of the above significant HIV-1 inhibitory effect, all 31 isolated polyoxypregnane glycosides were screened, followed by chemical work.

\section{Results and Discussion}

After a series of purification steps, 15 compounds were obtained from the roots of $M$. auricularis, and all of the compounds were identified to be $C_{21}$ steroidal glycosides with 2-deoxysugar units. Among them, two known compounds were marsdenosides M (5) and $L(6)$, determined by comparing their ${ }^{13} \mathrm{C}$ NMR data with the 
literature reported [4], and the other compounds (1-4 and 7-15) were identified to be new polyoxypregnane glycosides by analysis of NMR (including 1D and 2D NMR) and MS spectra.

Compound 1 had a molecular formula of $\mathrm{C}_{59} \mathrm{H}_{84} \mathrm{O}_{24}$ based on the HRESIMS ion $[\mathrm{M}+\mathrm{Na}]^{+}$at $\mathrm{m} / \mathrm{z} 1199.5303$. In the ${ }^{1} \mathrm{H}$ NMR spectrum, three methyl singlet signals at $\delta 1.55(3 \mathrm{H}, \mathrm{s}, \mathrm{H}-18), 1.54$ $(3 \mathrm{H}, \mathrm{s}, \mathrm{H}-19)$, and $1.99(3 \mathrm{H}, \mathrm{s}, \mathrm{H}-21)$ and three signals at $\delta 3.80$ $(1 \mathrm{H}, \mathrm{m}, \mathrm{H}-3), 5.97(1 \mathrm{H}, \mathrm{t}, \mathrm{J}=10.1 \mathrm{~Hz}, \mathrm{H}-11)$, and $5.59(1 \mathrm{H}, \mathrm{d}$, $J=10.1 \mathrm{~Hz}, \mathrm{H}-12$ ) corresponding to carbons with secondary oxidation were observed. Combination of ${ }^{1} \mathrm{H}$ and ${ }^{13} \mathrm{C}$ NMR data indicated 1 had a $\mathrm{C}_{21}$ steroidal skeleton. The proton signals at $\delta 6.77$ $(1 \mathrm{H}, \mathrm{qq}, J=7.1,1.4 \mathrm{~Hz}, \mathrm{Tig}-\mathrm{H}-3), 1.33(3 \mathrm{H}, \mathrm{d}, J=7.1$, Tig-H-4), $1.50(3 \mathrm{H}, \mathrm{s}, \mathrm{Tig}-\mathrm{H}-5), 8.15(2 \mathrm{H}, \mathrm{dd}, J=7.8,1.3 \mathrm{~Hz}, \mathrm{Bz}-\mathrm{H}-3,7)$, $7.36(2 \mathrm{H}, \mathrm{dd}, J=7.8,7.4 \mathrm{~Hz}, \mathrm{Bz}-\mathrm{H}-4,6)$, and $7.46(1 \mathrm{H}, \mathrm{t}$, $J=7.4 \mathrm{~Hz}, \mathrm{Bz}-\mathrm{H}-5)$ as well as two groups of characteristic carbon signals at $\delta 167.0$ (Tig-C-1), 128.6 (Tig-C-2), 138.7 (Tig-C-3), 14.1 (Tig-C-4), and 11.7 (Tig-C-5), 166.5 (Bz-C-1), 130.6 (BzC-2), 130.0 (Bz-C-3, 7), 128.8 (Bz-C-4, 6), and 133.5 (Bz-C-5) indicated the existence of a tigloyl and a benzyl group in the molecular structure. By the combined use of HSQC, HMBC, and ${ }^{1} \mathrm{H}-{ }^{-1} \mathrm{H}$ COSY experiments ( $\bullet$ Fig. 2 ), the proton and carbon signals of the aglycone moiety were assigned. In the ROESY spectrum, the dipolar interaction of $\mathrm{H}-11 / \mathrm{H}-19, \mathrm{H}-12 / \mathrm{H}-17, \mathrm{H}-12 / \mathrm{H}-9, \mathrm{H}-21 / \mathrm{H}-$ 18, $\mathrm{H}-9 / \mathrm{H}-4 \mathrm{a}, \mathrm{H}-9 / \mathrm{H}-1 \mathrm{a}, \mathrm{H}-3 / \mathrm{H}-4 \mathrm{a}, \mathrm{H}-3 / \mathrm{H}-1 \mathrm{a}$, and $\mathrm{H}-3 / \mathrm{H}-2 \mathrm{a}$ deduced the orientations of $\mathrm{H}-3, \mathrm{H}-11, \mathrm{H}-12$, and $\mathrm{H}-17$ to be $\alpha, \beta$, $\alpha$, and $\alpha$, respectively ( $\vee$ Fig. 3 ). Therefore, the aglycone structure

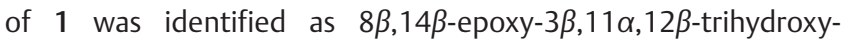
prengn-5-en-20-one, which is a new $C_{21}$ steroid skeleton. On the basis of HMBC correlations between $\delta 167.0$ (Tig-C-1) and 5.97 $(\mathrm{H}-11)$, and between $\delta 166.5(\mathrm{Bz}-\mathrm{C}-1)$ and $5.59(\mathrm{H}-12)$, the position of the tigloyl and benzyl groups were determined at $\mathrm{C}-11$ and $\mathrm{C}-12$, respectively ( $\bullet$ Fig. 2 ). The anomeric regions in the ${ }^{1} \mathrm{H}$ and ${ }^{13} \mathrm{C}$ NMR spectra presented four protons at $\delta 5.24(1 \mathrm{H}, \mathrm{d}$, $J=8.8 \mathrm{~Hz}), 5.19(1 \mathrm{H}, \mathrm{d}, J=7.9 \mathrm{~Hz}), 4.90(1 \mathrm{H}, \mathrm{d}, J=7.8 \mathrm{~Hz})$, and $4.76(1 \mathrm{H}, \mathrm{dd}, J=9.5,1.4 \mathrm{~Hz})$ and four carbon signals at $\delta 106.6$, $105.0,101.9$, and 97.9 , suggesting the existence of four sugar units in 1 . The $\beta$ configurations of the four sugars were determined based on each large coupling constant $(3 / 1,2>7 \mathrm{~Hz})$. Moreover, two methyl doublets at $\delta 1.56(3 \mathrm{H}, \mathrm{d}, J=5.3 \mathrm{~Hz}), 1.61(3 \mathrm{H}$, $\mathrm{d}, J=6.2 \mathrm{~Hz})$ and two methyl singlets at $\delta 3.48(3 \mathrm{H}, \mathrm{s}), 3.79(3 \mathrm{H}$, s) in the ${ }^{1} \mathrm{H}$ NMR spectrum indicated that two of the four sugar units were 6-deoxy-3-0-methly pyranoses [5]. Eventually, the sugar units were identified as oleandrose, 6-deoxy-3-O-methyl-allose, and two glucoses by NMR spectroscopic data analysis as well as by comparison with previously reported values. Using ${ }^{1} \mathrm{H}-{ }^{1} \mathrm{H}$ COSY, $\mathrm{HSQC}$, and HMBC spectra, the proton and carbon resonances of each sugar were fully assigned. The connectivity of the sugars was established by HMBC correlations between $\delta 5.24$ (Allo-H-1) and 83.3 (Ole-C-4), between $\delta 4.90\left(\mathrm{Glc}_{1}-\mathrm{H}-1\right)$ and 83.4 (Allo$\mathrm{C}-4)$, and between $\delta 5.19\left(\mathrm{Glc}_{2}-\mathrm{H}-1\right)$ and $81.5\left(\mathrm{Glc}_{1}-\mathrm{C}-4\right)$ ( $\vee$ Fig. 2). Therefore, the sugar moiety could be deduced as 3-O$\beta$-glucopyranosyl-( $1 \rightarrow 4$ )- $\beta$-glucopyranosyl-( $1 \rightarrow 4)$-6-deoxy-3-Omethyl- $\beta$-allopyranosyl-( $1 \rightarrow 4)$ - $\beta$-oleandropyranoside, well in agreement with those in the compounds isolated from the same plant [6-8]. Also, previous phytochemical studies suggested that the absolute configuration of the glucose, 6-deoxy-3-0-methylallose, and oleandrose from M. auricularis should be D [4-11]. Fur-

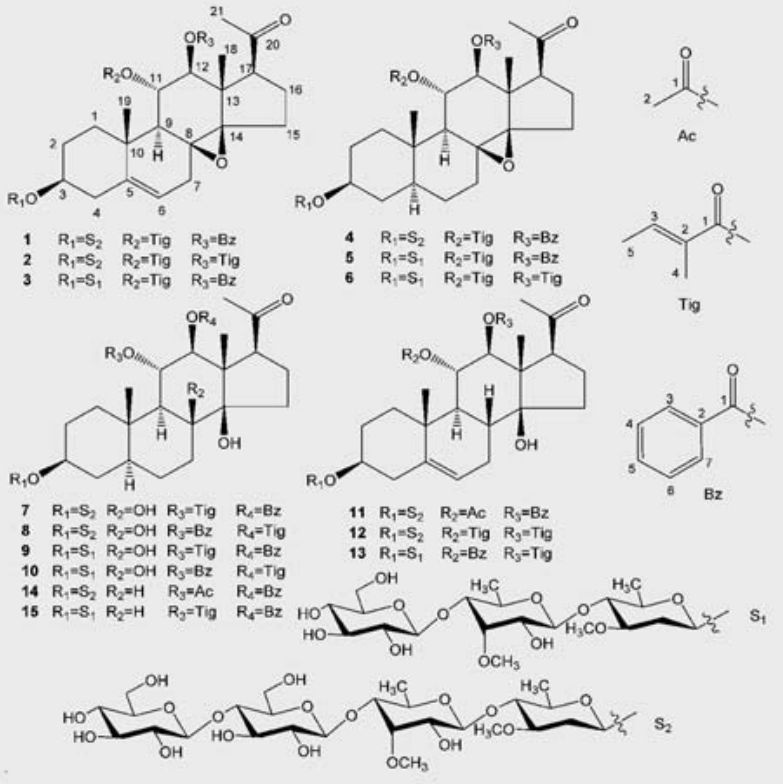

- Fig. 1 Structures of 1-15.

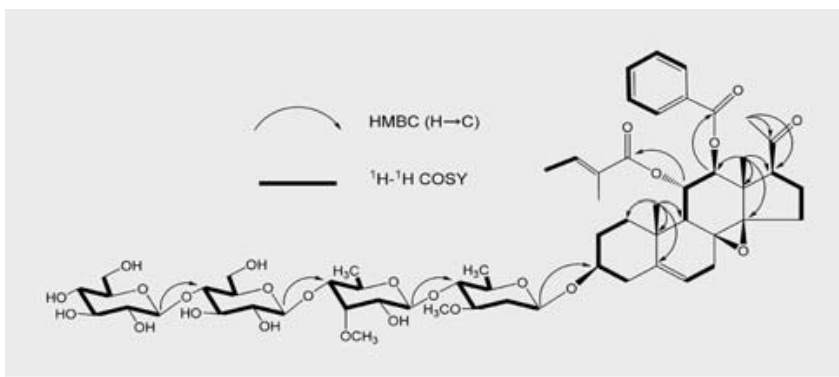

- Fig. 2 Key HMBC and ${ }^{1} \mathrm{H}-{ }^{1} \mathrm{H}$ COSY correlations for $\mathbf{1}$.

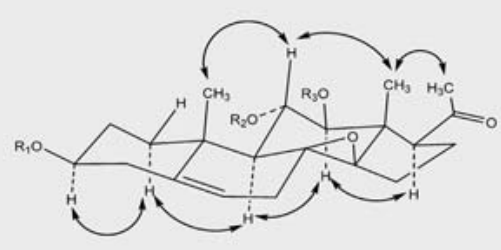

- Fig. 3 Key ROESY correlations of the aglycone for 1.

thermore, the glycosidation site was determined by HMBC correlations between $\delta 4.76$ (Ole-H-1) and 77.0 (C-3) ( Fig. 2). Consequently, the structure of 1 was elucidated as 3-O- $\beta$-D-glucopyranosyl-( $1 \rightarrow 4)$ - $\beta$-D-glucopyranosyl-( $1 \rightarrow 4)$-6-deoxy-3-O-methyl- $\beta$ D-allopyranosyl-( $1 \rightarrow 4)$ - $\beta$-D-oleandropyranosyl-11-O-tigloyl-12O-benzyl-8 $\beta, 14 \beta$-epoxy-3 $\beta, 11 \alpha, 12 \beta$-trihydroxyprengn-5-e-20one and named marstenacisside B10. 
Compound 2, with the molecular formula of $\mathrm{C}_{57} \mathrm{H}_{86} \mathrm{O}_{24}$ determined by the HRESIMS ion [M + Na] $]^{+}$at $\mathrm{m} / \mathrm{z} 1177.5454$, had the same sugar moiety and $C_{21}$ steroid skeleton as 1 based on comparison of their NMR data. In the ${ }^{13} \mathrm{C}$ NMR spectrum of 2 , the characteristic carbon signals at $\delta 167.1,167.0,138.6,138.4,128.9$, $128.8,14.3,14.2,12.0$, and 12.0 suggested the existence of double tigloyl groups in 2. By the combined use of HSQC, HMBC, and ${ }^{1} \mathrm{H}-{ }^{1} \mathrm{H}$ COSY experiments, the structure of 2 was finally elucidated as 3-O- $\beta$-D-glucopyranosyl-( $1 \rightarrow 4)$ - $\beta$-D-glucopyranosyl-( $1 \rightarrow 4)$-6deoxy-3-O-methyl- $\beta$-D-allopyranosyl- $(1 \rightarrow 4)-\beta$-D-oleandropyranosyl-11,12-O-ditigloyl-8 $\beta, 14 \beta$-epoxy-3 $\beta, 11 \alpha, 12 \beta$-tridroxypregnane-5-en-20-one and named marstenacisside B11.

Compound 3, with the molecular formula of $\mathrm{C}_{53} \mathrm{H}_{74} \mathrm{O}_{19}$ determined by the HRESIMS ion [M - H] ${ }^{-}$at $m / z$ 1013.4787, had the same $C_{21}$ steroid skeleton and ester groups as 1 by comparing their NMR data. The ${ }^{1} \mathrm{H}$ and ${ }^{13} \mathrm{C}$ NMR spectra of 3 showed three anomeric proton signals at $\delta 4.78(1 \mathrm{H}, \mathrm{d}, J=9.4 \mathrm{~Hz}), 4.99(1 \mathrm{H}, \mathrm{d}$, $J=7.7 \mathrm{~Hz})$, and $5.27(1 \mathrm{H}, \mathrm{d}, J=8.0 \mathrm{~Hz})$ and three anomeric carbon signals at $\delta 97.9,101.9$, and 106.6, suggesting that the sugar moiety of 3 was composed of three sugar units. The large coupling constants $(3 / 1,2>7 \mathrm{~Hz})$ deduced the $\beta$ configurations of the three sugars. Finally, the sugar units were identified as oleandrose, 6-deoxy-3-0-methyl-allose, and glucose by NMR spectroscopic data analysis as well as by comparison with previously reported values. Using ${ }^{1} \mathrm{H}-{ }^{1} \mathrm{H}$ COSY, HSQC, and $\mathrm{HMBC}$ spectra, the proton spin systems and the carbon resonances of three sugars were fully assigned. The HMBC correlations between $\delta 5.27$ (Allo-H-1) and 83.2 (Ole-C-4), and between $\delta 4.99$ (Glc-H-1) and 83.3 (Allo-C-4) established the sequence of the sugar chain. Therefore, the sugar moiety could be deduced as 3-O- $\beta$-glucopyranosyl-( $1 \rightarrow 4)$-6-deoxy-3-O-methyl- $\beta$-allopyranosyl-( $1 \rightarrow 4)$ - $\beta$-oleandropyranoside and well coincided with neo-condurangotriose in other compounds that were also isolated from $M$. tenacissima [9]. The glycosidation site was confirmed by the HMBC correlation between $\delta$ 4.78 (Ole-H-1) and 76.2 (C-3). Finally, the structure of 3 was elucidated to be $3-O-\beta$-D-glucopyranosyl-( $1 \rightarrow 4)$ - $\beta$-D-glucopyranosyl-( $1 \rightarrow 4)$-6-deoxy-3-O-methyl- $\beta$-D-allopyranosyl-( $1 \rightarrow 4)-\beta$-Doleandropyranosyl-11-O-tigloyl-12-0-benozyl-8 $\beta, 14 \beta$-epoxy$3 \beta, 11 \alpha, 12 \beta$-tridroxypregnane-5-en-20-one and named marstenacisside A8.

Compound 4 had the molecular formula $\mathrm{C}_{59} \mathrm{H}_{86} \mathrm{O}_{24}$, determined by the HRESIMS ion [M - H] $]^{-}$at $m / z$ 1177.5488, with two mass units more than that of 1 . NMR data comparison suggested that 4 and $\mathbf{1}$ had an almost identical structure except for the difference in the A-ring portion. In the ${ }^{13} \mathrm{C}$ NMR spectrum of 4 , the carbon signals of C-3 $(\delta 76.0), \mathrm{C}-4(\delta 35.0), \mathrm{C}-5(\delta 44.2), \mathrm{C}-6(\delta$ $27.4), C-7(\delta 32.5)$, and $C-19(\delta 13.1)$ deduced that 4 had the $s p^{3}$ carbons of $\mathrm{C}-5$ and $\mathrm{C}-6$. Thus, the $\mathrm{C}_{21}$ steroid skeleton of 4 could be deduced as $5 \alpha-8 \beta, 14 \beta$-epoxy- $3 \beta, 11 \alpha, 12 \beta$-tridroxypregnane20 -one, which is well in agreement with $17 \beta$-tenacigenin $\mathrm{B}$ [5, 11]. Confirmed by the combined use of ${ }^{1} \mathrm{H}-{ }^{1} \mathrm{H}$ COSY, HSQC, and HMBC experiments, the structure of 4 was finally elucidated as $3-$ $O$ - $\beta$-D-glucopyranosyl-( $1 \rightarrow 4)$ - $\beta$-D-glucopyranosyl-( $1 \rightarrow 4)$-6-deoxy-3-O-methyl- $\beta$-D-allopyranosyl-( $1 \rightarrow 4)$ - $\beta$-D-oleandropyranosyl-11-O-tigloyl-12-O-benozyl-5 $\alpha$ - $8 \beta, 14 \beta$-epoxy-3 $\beta, 11 \alpha, 12 \beta$-tridroxypregnane-20-one and named marstenacisside B12.
Compound 7, with a molecular formula of $\mathrm{C}_{59} \mathrm{H}_{88} \mathrm{O}_{25}$ determined by the HRESIMS ion $[\mathrm{M}-\mathrm{H}]^{-}$at $\mathrm{m} / \mathrm{z}$ 1195.5596, had two hydrogen atoms and one oxygen atom more than 4 . The ${ }^{13} \mathrm{C}$ NMR data of 7 suggested that it had almost the same carbon signals as 4 except for significant differences at C-8 and C-14. The difference of molecular formula and chemical shifts at C-8 $(\delta$ $78.4,+12.1 \mathrm{ppm})$ and $\mathrm{C}-14(85.6,+13.9 \mathrm{ppm})$ deduced, in the structure of 7, two free hydroxyl groups linked to the C-8 and C14 positions. Therefore, the $C_{21}$ steroid skeleton of 7 could be deduced as $5 \alpha-3 \beta, 11 \alpha, 8 \beta, 12 \beta, 14 \beta$-pentadroxypregnane-20-one, which well coincided with tenacigenin $C$ [10-12]. Confirmed by the combined use of ${ }^{1} \mathrm{H}-{ }^{1} \mathrm{H}$ COSY, HSQC, and $\mathrm{HMBC}$ experiments, the structure of 7 was elucidated to be 3-O- $\beta$-D-glucopyranosyl( $1 \rightarrow 4$ )- $\beta$-D-glucopyranosyl-( $1 \rightarrow 4)$-6-deoxy-3-O-methyl- $\beta$-D-allopyranosyl-( $1 \rightarrow 4)$ - $\beta$-D-oleandropyranosyl-11-O-tigloyl-12-O-benozyl-5 $\alpha$-3 $\beta, 11 \alpha, 8 \beta, 12 \beta, 14 \beta$-pentadroxypregnane-20-one and named marstenacisside B13.

Compound 8 had the same molecular formula of $\mathrm{C}_{59} \mathrm{H}_{88} \mathrm{O}_{25}$ as 7, which was determined by the HRESIMS ion [M $-\mathrm{H}]^{-}$at $m / z$ 1195.5588. The NMR data of 8 and 7 revealed that they had almost identical carbon signals. However, the carbon signals of 8 at $\delta 72.2(\mathrm{C}-11)$ and 78.8 (C-12) obviously differed from those of 7 at $\delta 71.3(\mathrm{C}-11)$ and $79.8(\mathrm{C}-12)$, suggesting they had the same ester groups but with different esterification positions. The HMBC correlations between $\delta 6.67(\mathrm{H}-11)$ and $166.0(\mathrm{Bz}-\mathrm{C}-1)$, and between $\delta 5.55(\mathrm{H}-12)$ and $170.0(\mathrm{Tig}-\mathrm{C}-1)$ determined the linkages of the benzoyl group to $\mathrm{C}-11$ and the tigloyl group to $\mathrm{C}-12$. By analyses of ${ }^{1} \mathrm{H}-{ }^{1} \mathrm{H}$ COSY, HSQC, and HMBC spectra, the NMR data of 8 were fully assigned. Thus, the structure of $\mathbf{8}$ was determined as 3-O- $\beta$-D-glucopyranosyl-( $1 \rightarrow 4)$ - $\beta$-D-glucopyranosyl-( $1 \rightarrow 4)$-6deoxy-3-O-methyl- $\beta$-D-allopyranosyl-( $1 \rightarrow 4)$ - $\beta$-D-oleandropyranosyl-11-O-benozyl-12-O-tigloyl-5 $\alpha$-3 $\beta, 11 \alpha, 8 \beta, 12 \beta, 14 \beta$-pentadroxypregnane-20-one and named marstenacisside B14.

Compound 9, with the molecular formula of $\mathrm{C}_{53} \mathrm{H}_{78} \mathrm{O}_{20}$ determined by the HRESIMS ion [M - H] $]^{-}$at $m / z$ 1033.5083, had the same aglycone moiety as 7 by comparison of their NMR data. In the ${ }^{1} \mathrm{H}$ and ${ }^{13} \mathrm{C}$ NMR spectra of 9 , three anomeric protons at $\delta$ $4.82(1 \mathrm{H}, \mathrm{d}, J=9.7 \mathrm{~Hz}), 4.99(1 \mathrm{H}, \mathrm{d}, J=7.7 \mathrm{~Hz})$, and $5.29(1 \mathrm{H}, \mathrm{d}$, $J=8.0 \mathrm{~Hz}$ ) and three anomeric carbons at $\delta 97.5,101.9$, and 106.6 were observed. Compound 9 had the same sugar moiety as 3 by comparing their NMR data of the sugar moiety. Therefore, the structure of 9 was elucidated to be 3-O- $\beta$-D-glucopyranosyl( $1 \rightarrow 4$ )-6-deoxy-3-O-methyl- $\beta$-D-allopyranosyl-( $1 \rightarrow 4)$ - $\beta$-D-oleandropyranosyl-11-O-tigloyl-12-O-benozyl-5 $\alpha$-3 $\beta, 11 \alpha, 8 \beta, 12 \beta$, $14 \beta$-pentadroxypregnane-20-one and named marstenacisside A9.

Compound 10, with the molecular formula of $\mathrm{C}_{53} \mathrm{H}_{78} \mathrm{O}_{20}$ determined by the HRESIMS ion $[\mathrm{M}-\mathrm{H}]^{-}$at $\mathrm{m} / \mathrm{z} 1033.5059$, was an isomer of 9 . The NMR data suggested that 10 had almost identical carbon signals as 9. The carbon signals of 10 at $\delta 72.2(\mathrm{C}-11)$ and 78.8 (C-12), obviously different with those of 9 at $\delta 71.3$ (C-11) and $79.8(\mathrm{C}-12)$, suggested that they had the same ester groups but with different esterification positions. Further comparison of the aglycone NMR data of 10 and $\mathbf{8}$ deduced that they had the same aglycone. Consequently, the structure of 10 was elucidated to be 3-O- $\beta$-D-glucopyranosyl-( $1 \rightarrow 4)$-6-deoxy-3-O-methyl- $\beta$-Dallopyranosyl-(1 $\rightarrow 4$ )- $\beta$-D-oleandropyranosyl-11-O-benozyl-12-O- 
tigloyl-5 $\alpha$-3 $\beta, 11 \alpha, 8 \beta, 12 \beta, 14 \beta$-pentadroxypregnane-20-one and named marstenacisside $\mathrm{A} 10$.

Compound 11 had a molecular formula of $\mathrm{C}_{56} \mathrm{H}_{82} \mathrm{O}_{24}$ as determined by the HRESIMS ion $[\mathrm{M}-\mathrm{H}]^{-}$at $\mathrm{m} / \mathrm{z}$ 1137.5137. The NMR data of 11 suggested that it had the same sugar moiety as 1 . In the ${ }^{13} \mathrm{C}$ NMR spectra of 11 , two olefinic carbon signals at $\delta 139.7$ and 122.6 deduced the double bond at $\mathrm{C}-5$ and $\mathrm{C}-6$, and four oxidative carbons at $\delta 77.3$ (C-3), 71.8 (C-11), 78.6 (C-12), and 84.1 (C-14) suggested the existence of four hydroxyl groups in the aglycone. By comparing the NMR data of 11 with those compounds in the literature, the $C_{21}$ steroid skeleton of 11 was deduced to be $3 \beta, 11 \alpha, 12 \beta, 14 \beta$-tetrahydroxyprengn-5-en-20-one, well in agreement with drevogenin $\mathrm{P}$ [13]. Characteristic carbon signals at $\delta 170.2$ and 21.3 along with 166.8, 133.4, $130.2(\times 2)$, 130.1 , and $129.2(\times 2)$ indicated the existence of an acetyl group and a benzyl group in the molecular structure. Based on the HMBC correlations between $\delta 170.4$ (Ac-C-11) and $5.85(\mathrm{H}-11)$, and between $\delta 166.8(\mathrm{Bz}-\mathrm{C}-1)$ and $5.43(\mathrm{H}-12)$, the linkages of an acetyl group to $\mathrm{C}-11$ and a benzoyl group to $\mathrm{C}-12$ were determined. Finally, confirmed by the combined use of ${ }^{1} \mathrm{H}-{ }^{1} \mathrm{H}$ COSY, $\mathrm{HSQC}$, and HMBC experiments, the structure of 11 was elucidated as 3-O- $\beta$-D-glucopyranosyl-( $1 \rightarrow 4)$ - $\beta$-D-glucopyranosyl-( $1 \rightarrow 4)$-6deoxy-3-O-methyl- $\beta$-D-allopyranosyl-( $1 \rightarrow 4)$ - $\beta$-D-oleandropyranosyl-11-O-acetyl-12-O-benozyl-3 $\beta, 11 \alpha, 12 \beta, 14 \beta$-tetrahydroxy-

prengn-5-en-20-one and named marstenacisside B15.

Compound 12, with a molecular formula of $\mathrm{C}_{57} \mathrm{H}_{88} \mathrm{O}_{24}$ as determined by the HRESIMS ion $[\mathrm{M}-\mathrm{H}]^{-}$at $\mathrm{m} / \mathrm{z} 1155.5636$, had the same $C_{21}$ steroidal skeleton structure as 11 by comparing their NMR data. In the ${ }^{13} \mathrm{C}$ NMR spectrum of 12 , characteristic carbon signals at $\delta 167.9,167.1,138.6,138.5,129.0,128.5,14.3,14.3$, 12.1 , and 12.0 suggested the existence of double tigloyl groups in the molecule. By the combined use of ${ }^{1} \mathrm{H}-{ }^{1} \mathrm{H}$ COSY, HSQC, and HMBC experiments, the structure of 12 was elucidated as 3-O- $\beta$ D-glucopyranosyl-( $1 \rightarrow 4)$ - $\beta$-D-glucopyranosyl-( $1 \rightarrow 4$ )-6-deoxy-3$O$-methyl- $\beta$-D-allopyranosyl-( $1 \rightarrow 4)$ - $\beta$-D-oleandropyranosyl-

11,12-O-ditigloyl-3 $\beta, 11 \alpha, 12 \beta, 14 \beta$-tetrahydroxyprengn-5-en-20one and named marstenacisside B16.

Compound 13 had a molecular formula of $\mathrm{C}_{53} \mathrm{H}_{76} \mathrm{O}_{19}$ determined by the HRESIMS ion [M - H] $]^{-}$at $\mathrm{m} / \mathrm{z}$ 1015.4949. The NMR data of 13 suggested that it had same $C_{21}$ steroid skeleton as 11 and 12. In the ${ }^{13} \mathrm{C}$ NMR spectrum of 13 , two groups of characteristic carbon signals at $\delta 166.2,133.4,130.8,130.1(\times 2)$, and $128.8(\times 2)$ and at $\delta 167.8,128.3,138.8,14.2$, and 11.9, coincided well with those of 8 , suggesting that 13 had a benzoyl group and a tigloyl group in the molecule. By comparing the carbon chemical shifts of the ester groups as well as the carbon chemical shifts of $\mathrm{C}-11$ and $\mathrm{C}-12$, the linkages of benzoyl to $\mathrm{C}-11$ and tigloyl to $\mathrm{C}-12$ were also the same as those in 8 . Moreover, the sugar moiety of 13 was deduced to be the same as that of 3 by comparing their NMR data. Thus, the structure of 13 was elucidated as 3-O- $\beta$ D-glucopyranosyl-(1 $\rightarrow$ 4)-6-deoxy-3-O-methyl- $\beta$-D-allopyranosyl$(1 \rightarrow 4)$ - $\beta$-D-oleandropyranosyl-11-O-benozyl-12-O-tigloyl-3 $\beta$,

$11 \alpha, 12 \beta, 14 \beta$-tetrahydroxyprengn-5-en-20-one and named marstenacisside $\mathrm{A} 11$.

Compound 14 had a molecular formula of $\mathrm{C}_{56} \mathrm{H}_{84} \mathrm{O}_{24}$ as determined by the HRESIMS ion $[\mathrm{M}-\mathrm{H}]^{-}$at $\mathrm{m} / \mathrm{z} 1139.5333$, two mass units more than that of 11 . The NMR data of 14 suggested that it had the almost identical $C_{21}$ steroid skeleton as 11 , except for the significant difference in the A-ring portion. In the ${ }^{13} \mathrm{C}$ NMR spectrum of 14 , carbon signals of $\mathrm{C}-3(\delta 76.2), \mathrm{C}-4(\delta 35.5), \mathrm{C}-5(\delta$ $44.7), C-6(\delta 29.4), C-7(\delta 28.4)$, and C-19 $(\delta 12.4)$ indicated that 14 had the $s p^{3}$ carbons of $C-5$ and $C-6$. Thus, the $C_{21}$ steroid skeleton was deduced to be $5 \alpha-3 \beta, 11 \alpha, 12 \beta, 14 \beta$-tetrdroxypregnane20-one, well in agreement with decaylconduragogenin A [12]. Therefore, by using ${ }^{1} \mathrm{H}-{ }^{1} \mathrm{H}$ COSY, HSQC, and HMBC experiments, the structure of 14 was elucidated as 3-O- $\beta$-D-glucopyranosyl( $1 \rightarrow 4$ )- $\beta$-D-glucopyranosyl-( $1 \rightarrow 4$ )-6-deoxy-3-O-methyl- $\beta$-D-allopyranosyl-( $1 \rightarrow 4)$ - $\beta$-D-oleandropyranosyl-11-O-acetyl-12-O-benozyl-5 $\alpha$-3 $\beta, 11 \alpha, 12 \beta, 14 \beta$-tetrdroxypregnane-20-one and named marstenacisside B17.

Compound 15 had a molecular formula of $\mathrm{C}_{53} \mathrm{H}_{78} \mathrm{O}_{19}$ as determined by the HRESIMS ion $[\mathrm{M}-\mathrm{H}]^{-}$at $\mathrm{m} / \mathrm{z} 1017.5085$. The NMR data suggested that its $C_{21}$ steroid skeleton is same as that of 14 . In the ${ }^{13} \mathrm{C}$ NMR spectrum of 15 , two groups of characteristic carbon signals at $\delta 167.4,128.9,138.6,14.1$, and 11.7 and at $\delta$ $166.8,133.7,130.3,130.1(\times 2)$, and $128.9(\times 2)$ suggested that it had a tigloyl group and a benzoyl group. The linkages of the tigloyl group to $\mathrm{C} 11$ and the benzoyl group to $\mathrm{C}-12$ were determined by the HMBC correlations between $\delta 167.4$ (Tig-C-1) and $5.87(\mathrm{H}-11)$, and between $166.8(\mathrm{Bz}-\mathrm{C}-1)$ and $5.43(\mathrm{H}-12)$. The sugar moiety of 15 was deduced to be the same as 3 by comparing the NMR data. Consequently, confirmed by the combined use of ${ }^{1} \mathrm{H}-{ }^{1} \mathrm{H}$ COSY, HSQC, and HMBC experiments, the structure of 15 was elucidated as 3-O- $\beta$-D-glucopyranosyl-6-deoxy-3-O-methyl- $\beta$ D-allopyranosyl-( $1 \rightarrow 4)$ - $\beta$-D-oleandropyranosyl-11-O-tigloyl-12-

$O$-benozyl-5 $\alpha$-3 $\beta, 11 \alpha, 12 \beta, 14 \beta$-tetrdroxypregnane-20-one and named marstenacisside $\mathrm{A} 12$.

Isolates 1-15 above and the previously isolated 16 polyoxypregnane glycosides, marstenacissides A1-A7 and B1-B9 [2], were further evaluated for anti-HIV and cytotoxic activities. As illustrated in $>$ Table 1, treatment of HIV-1-infected SupT1 cells with $6,11,12,14$, marstenacissides $A 3, A 4$, and marstenacissides $\mathrm{B} 1, \mathrm{~B} 3$, and $\mathrm{B} 9(30 \mu \mathrm{M})$ slightly inhibited HIV-1 replication, indicating that these compounds only had a marginal inhibitory effect on HIV-1, while the other compounds exhibited negligible effects since their inhibition rates were far below average. The toxicity test showed that all 31 compounds at the concentration of $30 \mu \mathrm{M}$ displayed different cytoxicities against SupT1 cells (cell survival rate from $30 \%$ to $71 \%$ ), while no linear relationship between toxicity and anti-HIV activity was observed.

The EtOAc-soluble fraction of the $95 \% \mathrm{EtOH}$ extract from M. auricularis roots showed a significant HIV-1 inhibitory effect, while all of the isolated polyoxypregnane glycosides showed marginal and negligible inhibitory effects on HIV-1, which suggested that a further chemical investigation on this traditional medicine is needed to explore bioactive constituents against HIV-1.

\section{Materials and Methods}

\section{General experimental procedures}

NMR spectra were recorded on a Bruker DRX-500 spectrometer (500 MHz for ${ }^{1} \mathrm{H}$ NMR and $125 \mathrm{MHz}$ for ${ }^{13} \mathrm{C}-\mathrm{NMR}$ ) and a Varian UNITY INOVA 600 spectrometer $\left(600 \mathrm{MHz}\right.$ for ${ }^{1} \mathrm{H}$ NMR and 
$150 \mathrm{MHz}$ for ${ }^{13} \mathrm{C}-\mathrm{NMR}$ ) in pyridine- $d_{5}$ (Sigma-Aldrich), and the chemical shifts are given in $\delta$ (ppm). HRESIMS was performed on the Synapt MS (Waters Corporation). Optical rotations were measured with the Perkin-Elmer 343 polarimeter (PerkinElmer) and JASCO J-810 polarimeter (JASCO Corporation). UV data were recorded on a UV-2500 spectrophotometer (MAPADA Corporation). HPLC analyses were performed on an Agilent 1100 series (Agilent Technologies) equipped with an Alltech 2000 evaporative light scattering detector (temp: $110^{\circ} \mathrm{C}$, gas: $2.4 \mathrm{~L} / \mathrm{min}$, Alltech Corporation) and a Techmate $\mathrm{C} 18$ column $(4.6 \mathrm{~mm} \times 250 \mathrm{~mm}$, ODS, $5 \mu \mathrm{m}$, Techmate Co. Ltd.). Semipreparative HPLC separations were carried out using a system consisting of an NP7000 module (Hanbon Co. Ltd.), a Shodex RID 102 detector (Showa Denko Group), and a Venusil XBP C18 column $(8.0 \mathrm{~mm} \times 250 \mathrm{~mm}$, ODS, $5 \mu \mathrm{m}$, Bonna-Agela Technologies). Silica gel H (Qingdao marine Chemical), $\mathrm{MCl}$ resin (50 $\mu \mathrm{m}$, Mitsubishi Chemicals), and ODS (Octadecylsilyl) silica gel ( $120 \AA$, $50 \mu \mathrm{m}, \mathrm{YMC})$ were used for column chromatography performance.

\section{Plant material}

The roots of $M$. tenacissima were collected from Zhenyuan, Simao, Yunnan province of China and were identified by Prof. Li-Xia Zhang. A voucher specimen (NO.111010) was deposited in the herbarium of the Beijing Institute of Radiation Medicine, Beijing, China.

\section{Extraction and isolation}

The dried roots of $M$. tenacissima $(3 \mathrm{~kg})$ were crushed and extracted with $95 \% \mathrm{EtOH}(24 \mathrm{~L})$ at $120^{\circ} \mathrm{C}$ three times (each time for $1 \mathrm{~h})$. The filtrate was concentrated in vacuo to yield an extract and then partitioned between EtOAc and $\mathrm{H}_{2} \mathrm{O}$. After concentration, the residue $(78 \mathrm{~g})$ of the EtOAc extract was separated on a silica gel column $(10 \mathrm{~cm} \times 24 \mathrm{~cm})$ eluted with a gradient consisting of $\mathrm{CH}_{3} \mathrm{Cl}_{3}-\mathrm{MeOH}(\mathrm{v} / \mathrm{v}, 50: 1 \rightarrow 7: 1)$ to afford 374 fractions (Fr.1 1374 , each fraction $150 \mathrm{ml})$.

$\mathrm{Fr}_{.1}$ 195-214 (6.5 g) was subjected to an $\mathrm{MCl}$ resin column $(5 \mathrm{~cm} \times 20 \mathrm{~cm})$ eluted with $\mathrm{MeOH}-\mathrm{H}_{2} \mathrm{O}$ to afford 17 fractions $(\mathrm{v} / \mathrm{v}$, $70: 30$ for $F r .2$ 1-13; v/v, 80:20 for Fr.2 14-17, each fraction $250 \mathrm{ml}$ ). Fr.2 8 (225 mg) was separated by semipreparative HPLC with $\mathrm{CH}_{3} \mathrm{OH}-\mathrm{H}_{2} \mathrm{O}(\mathrm{v} / \mathrm{v}, 69: 31$, flow rate $5.0 \mathrm{~mL} / \mathrm{min})$ to give compound 6 (12.6 mg, $\left.t_{R} 23.2 \mathrm{~min}\right)$, and Fr.2 $9(261 \mathrm{mg})$ was purified by semipreparative $\mathrm{HPLC}$ with $\mathrm{CH}_{3} \mathrm{OH}-\mathrm{H}_{2} \mathrm{O}(\mathrm{v} / \mathrm{v}, 70: 30$, flow rate $4.5 \mathrm{~mL} / \mathrm{min}$ ) to yield an additional compound $6\left(23.8 \mathrm{mg}, t_{R}\right.$ $25.0 \mathrm{~min})$. Fr.2 14-15 (745 mg) was loaded on an ODS C18 column $(2 \mathrm{~cm} \times 30 \mathrm{~cm})$ eluted with $\mathrm{CH}_{3} \mathrm{OH}-\mathrm{H}_{2} \mathrm{O}(\mathrm{v} / \mathrm{v}, 67: 33)$ to give 16 fractions (Fr.3 1-16, each $50 \mathrm{~mL}$ ). Then Fr.3 9-11 (293 mg) was separated by semipreparative HPLC with $\mathrm{CH}_{3} \mathrm{OH}-\mathrm{H}_{2} \mathrm{O}(\mathrm{v} / \mathrm{v}, 69: 31$, flow rate $4.5 \mathrm{~mL} / \mathrm{min}$ ) to give mixture $\mathrm{A}\left(t_{\mathrm{R}} 27.0 \mathrm{~min}\right)$, and $\mathrm{Fr} .3$ 1316 (290 mg) was separated by semipreparative HPLC with $\mathrm{CH}_{3} \mathrm{OH}-\mathrm{H}_{2} \mathrm{O}(\mathrm{v} / \mathrm{v}, 70: 30$, flow rate $4.5 \mathrm{~mL} / \mathrm{min})$ to give mixtures $\mathrm{B}$ $\left(t_{R} 20.5 \mathrm{~min}\right)$ and $C\left(t_{R} 22.5 \mathrm{~min}\right)$. Furthermore, mixture $A$ was purified by semipreparative HPLC with $\mathrm{CH}_{3} \mathrm{CN}-\mathrm{H}_{2} \mathrm{O}(\mathrm{v} / \mathrm{v}, 45: 55$, flow rate $4.5 \mathrm{~mL} / \mathrm{min}$ ) to yield compounds 5 (66.8 $\mathrm{mg}, t_{\mathrm{R}} 38.0 \mathrm{~min}$ ) and 3 (24.6 mg, $t_{R} 42.5 \mathrm{~min}$ ). Mixture $B$ was purified by semipreparative HPLC with $\mathrm{CH}_{3} \mathrm{CN}-\mathrm{H}_{2} \mathrm{O}(\mathrm{v} / \mathrm{v}, 45: 55$, flow rate $4.5 \mathrm{~mL} / \mathrm{min})$ to yield compounds $9\left(21.4 \mathrm{mg}, t_{R} 39.0 \mathrm{~min}\right)$ and 10 (45.5 mg, $t_{R}$ $42.1 \mathrm{~min})$. Mixture $C$ was purified by semipreparative HPLC with
- Table 1 HIV-1 inhibition rate and cell survival rate $(\bar{x} \pm s, n=3)$ of 31 polyoxypregnane glycosides from the roots of $M$. tenacissima.

\begin{tabular}{|c|c|c|c|}
\hline Compounds & Dose & $\begin{array}{l}\text { Inhibition } \\
\text { rate (\%) }\end{array}$ & $\begin{array}{l}\text { Cell survival } \\
\text { rate (\%) }\end{array}$ \\
\hline Efavirenz & $\begin{array}{r}0.0- \\
1 \mu \mathrm{M}\end{array}$ & $99.91 \pm 0.10$ & $99.51 \pm 0.03$ \\
\hline ฐ1 & $30 \mu \mathrm{M}$ & $13.70 \pm 4.66$ & $43.37 \pm 14.98$ \\
\hline 2 & $30 \mu \mathrm{M}$ & $20.90 \pm 5.17$ & $50.21 \pm 5.94$ \\
\hline 3 & $30 \mu \mathrm{M}$ & $13.478 \pm 4.66$ & $53.18 \pm 13.03$ \\
\hline 4 & $30 \mu \mathrm{M}$ & $21.19 \pm 5.36$ & $49.36 \pm 2.12$ \\
\hline 5 & $30 \mu \mathrm{M}$ & $8.26 \pm 2.77$ & $57.47 \pm 5.78$ \\
\hline 6 & $30 \mu \mathrm{M}$ & $39.26 \pm 5.56$ & $48.56 \pm 13.77$ \\
\hline 7 & $30 \mu \mathrm{M}$ & $29.09 \pm 1.87$ & $42.48 \pm 1.03$ \\
\hline 8 & $30 \mu \mathrm{M}$ & $31.36 \pm 6.96$ & $57.86 \pm 3.49$ \\
\hline 9 & $30 \mu \mathrm{M}$ & $29.77 \pm 5.90$ & $71.21 \pm 8.46$ \\
\hline 10 & $30 \mu \mathrm{M}$ & $25.57 \pm 0.99$ & $35.62 \pm 9.40$ \\
\hline 11 & $30 \mu \mathrm{M}$ & $47.75 \pm 4.73$ & $39.26 \pm 0.54$ \\
\hline 12 & $30 \mu \mathrm{M}$ & $37.81 \pm 4.23$ & $58.56 \pm 3.15$ \\
\hline 13 & $30 \mu \mathrm{M}$ & $20.06 \pm 2.46$ & $38.64 \pm 5.81$ \\
\hline 14 & $30 \mu \mathrm{M}$ & $36.87 \pm 8.27$ & $41.10 \pm 10.73$ \\
\hline 15 & $30 \mu \mathrm{M}$ & $25.52 \pm 3.87$ & $64.60 \pm 8.02$ \\
\hline Marstenacisside A1 & $30 \mu \mathrm{M}$ & $14.12 \pm 1.75$ & $42.05 \pm 6.51$ \\
\hline Marstenacisside A2 & $30 \mu \mathrm{M}$ & $16.48 \pm 1.39$ & $34.07 \pm 1.68$ \\
\hline Marstenacisside A3 & $30 \mu \mathrm{M}$ & $53.48 \pm 9.48$ & $30.29 \pm 1.91$ \\
\hline Marstenacisside A4 & $30 \mu \mathrm{M}$ & $39.74 \pm 4.56$ & $50.61 \pm 0.88$ \\
\hline Marstenacisside A5 & $30 \mu \mathrm{M}$ & $24.78 \pm 4.41$ & $38.12 \pm 3.01$ \\
\hline Marstenacisside A6 & $30 \mu \mathrm{M}$ & $25.14 \pm 7.21$ & $29.44 \pm 6.52$ \\
\hline Marstenacisside A7 & $30 \mu \mathrm{M}$ & $15.63 \pm 3.82$ & $69.90 \pm 4.80$ \\
\hline Marstenacisside B1 & $30 \mu \mathrm{M}$ & $41.32 \pm 5.32$ & $51.75 \pm 3.61$ \\
\hline Marstenacisside B2 & $30 \mu \mathrm{M}$ & $28.35 \pm 3.69$ & $56.53 \pm 11.76$ \\
\hline Marstenacisside B3 & $30 \mu \mathrm{M}$ & $48.83 \pm 7.96$ & $45.64 \pm 1.69$ \\
\hline Marstenacisside B4 & $30 \mu \mathrm{M}$ & $17.02 \pm 6.04$ & $62.22 \pm 5.64$ \\
\hline Marstenacisside B5 & $30 \mu \mathrm{M}$ & $33.81 \pm 8.56$ & $31.55 \pm 2.68$ \\
\hline Marstenacisside B6 & $30 \mu \mathrm{M}$ & $24.15 \pm 5.03$ & $39.63 \pm 8.07$ \\
\hline Marstenacisside B7 & $30 \mu \mathrm{M}$ & $22.54 \pm 6.11$ & $55.77 \pm 2.13$ \\
\hline Marstenacisside B8 & $30 \mu \mathrm{M}$ & $32.42 \pm 6.73$ & $60.34 \pm 3.64$ \\
\hline Marstenacisside B9 & $30 \mu \mathrm{M}$ & $39.20 \pm 5.73$ & $48.32 \pm 0.61$ \\
\hline
\end{tabular}

$\mathrm{CH}_{3} \mathrm{CN}-\mathrm{H}_{2} \mathrm{O}(\mathrm{v} / \mathrm{v}, 45: 55$, flow rate $5.0 \mathrm{~mL} / \mathrm{min})$ to yield compounds 15 (21.4 mg, $\left.t_{R} 36.2 \mathrm{~min}\right)$ and 13 (45.5 mg, $\left.t_{\mathrm{R}} 39.6 \mathrm{~min}\right)$.

Fr. $1300-323(6.0 \mathrm{~g})$ was subjected to an $\mathrm{MCl}$ resin column $(5 \mathrm{~cm} \times 20 \mathrm{~cm})$ eluted with $\mathrm{MeOH}-\mathrm{H}_{2} \mathrm{O}$ to afford 30 fractions $(\mathrm{v} / \mathrm{v}$, $70: 30$ for Fr.4 1-21; v/v, 75:25 for Fr.4 22-30, each fraction $250 \mathrm{~mL}$ ). Fr.4 16-19 (346.5 mg) was separated by semipreparative $\mathrm{HPLC}$ with $\mathrm{CH}_{3} \mathrm{OH}-\mathrm{H}_{2} \mathrm{O}(\mathrm{v} / \mathrm{v}, 66: 34$, flow rate $3.5 \mathrm{~mL} / \mathrm{min})$ to yield compound $12\left(50.1 \mathrm{mg}, t_{\mathrm{R}} 50.1 \mathrm{~min}\right)$, and mixtures $\mathrm{D}\left(21.5 \mathrm{mg}, t_{\mathrm{R}}\right.$ $32.3 \mathrm{~min}$ ) and $\mathrm{E}$ (45.4 mg, $\left.t_{\mathrm{R}} 42.4 \mathrm{~min}\right)$. Fr. 4 20-21 (214.4 mg) was separated by semipreparative HPLC with $\mathrm{CH}_{3} \mathrm{OH}-\mathrm{H}_{2} \mathrm{O}(\mathrm{v} / \mathrm{v}, 66: 34$, flow rate $3.5 \mathrm{~mL} / \mathrm{min}$ ) to obtain the additional mixtures $\mathrm{D}$ (43.1 mg, $\left.t_{R} 30.1 \mathrm{~min}\right)$ and $\mathrm{E}\left(24.5 \mathrm{mg}, t_{\mathrm{R}} 40.5 \mathrm{~min}\right)$. Fr.4 22-25 $(750 \mathrm{mg})$ was loaded on an ODS $\mathrm{C}_{18}$ column $(2 \mathrm{~cm} \times 30 \mathrm{~cm})$ eluted 
with $\mathrm{CH}_{3} \mathrm{OH}-\mathrm{H}_{2} \mathrm{O}(\mathrm{v} / \mathrm{v}, 64: 33-70: 30)$ to give $\mathrm{Fr}_{.5}$ 12-16 (each $50 \mathrm{~mL}$ ) and $\mathrm{Fr} .517$ (MeOH elution). Fr.5 12-16 (239.5 mg) was separated by semipreparative $\mathrm{HPLC}$ with $\mathrm{CH}_{3} \mathrm{OH}-\mathrm{H}_{2} \mathrm{O}(\mathrm{v} / \mathrm{v}, 69$ : 31, flow rate $4.0 \mathrm{~mL} / \mathrm{min})$ to afford an additional mixture $\mathrm{E}\left(42.6 \mathrm{mg}, t_{\mathrm{R}}\right.$ $35.3 \mathrm{~min})$ as well as mixture $\mathrm{F}\left(83.8 \mathrm{mg}, t_{R} 39.5 \mathrm{~min}\right)$. Fr.5 17 $(360 \mathrm{mg})$ was separated by semipreparative HPLC with $\mathrm{CH}_{3} \mathrm{OH}-\mathrm{H}_{2} \mathrm{O}(\mathrm{v} / \mathrm{v}, 70: 30$, flow rate $4.0 \mathrm{~mL} / \mathrm{min})$ to give mixture $\mathrm{G}$ (76.7 mg, $t_{R} 37.3 \mathrm{~min}$ ). Then, the combined mixture $\mathrm{D}$ was purified by semipreparative HPLC with $\mathrm{CH}_{3} \mathrm{CN}-\mathrm{H}_{2} \mathrm{O}(\mathrm{v} / \mathrm{v}, 35: 65$, flow rate $4.5 \mathrm{~mL} / \mathrm{min}$ ) to give compounds $14\left(13.8 \mathrm{mg}, t_{\mathrm{R}} 49.7 \mathrm{~min}\right)$ and 11 ( $26.7 \mathrm{mg}, t_{\mathrm{R}} 52.0 \mathrm{~min}$ ). The combined mixture $\mathrm{E}$ was purified by semipreparative HPLC with $\mathrm{CH}_{3} \mathrm{CN}-\mathrm{H}_{2} \mathrm{O}(\mathrm{v} / \mathrm{v}, 40: 60$, flow rate $4.5 \mathrm{~mL} / \mathrm{min}$ ) to give compound 2 (11.1 mg, $\left.t_{R} 41.0 \mathrm{~min}\right)$. Mixture $\mathrm{F}$ was purified by semipreparative $\mathrm{HPLC}$ with $\mathrm{CH}_{3} \mathrm{CN}-\mathrm{H}_{2} \mathrm{O}(\mathrm{v} / \mathrm{v}$, $40: 60$, flow rate $4.5 \mathrm{~mL} / \mathrm{min}$ ) to give compounds $4\left(45.5 \mathrm{mg}, t_{R}\right.$ $40.6 \mathrm{~min}$ ) and 1 ( $15.5 \mathrm{mg}, t_{\mathrm{R}} 41.4 \mathrm{~min}$ ). Mixture $\mathrm{G}$ was purified by semipreparative HPLC with $\mathrm{CH}_{3} \mathrm{CN}_{-} \mathrm{H}_{2} \mathrm{O}(\mathrm{v} / \mathrm{v}, 40: 60$, flow rate $4.0 \mathrm{~mL} / \mathrm{min})$ to give compounds $7\left(20.5 \mathrm{mg}, t_{\mathrm{R}} 35.2 \mathrm{~min}\right)$ and 8 (30.0 mg, $\left.t_{R} 40.1 \mathrm{~min}\right)$.

\section{Characterization}

Marstenacisside B10 (1): white amorphous powder; $[\alpha]_{\mathrm{D}}^{20}=+14.2$ ( $c=0.059$, pyridine). UV (MeOH) $\lambda_{\max } 225.8(\varepsilon$ 16354) nm. $\mathrm{C}_{59} \mathrm{H}_{84} \mathrm{O}_{24}$, HRESIMS (positive): $\mathrm{m} / z 1199.5303$ [M + Na] ${ }^{+}$(calcd. for $\mathrm{C}_{59} \mathrm{H}_{84} \mathrm{O}_{24} \mathrm{Na}$ : 1199.5250$)$. ${ }^{1} \mathrm{H}$ NMR data $(600 \mathrm{MHz}$, pyridine$\left.d_{5}\right)$ : $\delta 3.80(1 \mathrm{H}, \mathrm{m}, \mathrm{H}-3), 5.97(1 \mathrm{H}, \mathrm{t}, J=10.1 \mathrm{~Hz}, \mathrm{H}-11), 5.59$ $(1 \mathrm{H}, \mathrm{d}, J=10.1 \mathrm{~Hz}, \mathrm{H}-12), 3.11(1 \mathrm{H}, \mathrm{dd}, J=11.2,6.2 \mathrm{~Hz}, \mathrm{H}-17)$, $1.55\left(3 \mathrm{H}, \mathrm{s}, 18-\mathrm{CH}_{3}\right), 1.54\left(3 \mathrm{H}, \mathrm{s}, 19-\mathrm{CH}_{3}\right), 1.99\left(3 \mathrm{H}, \mathrm{s}, 21-\mathrm{CH}_{3}\right)$, $6.77(1 \mathrm{H}, \mathrm{qq}, \mathrm{J}=7.1,1.4 \mathrm{~Hz}$, Tig- $\mathrm{H}-3), 1.33(3 \mathrm{H}, \mathrm{d}, \mathrm{J}=7.1 \mathrm{~Hz}$, Tig$\mathrm{H}-4), 1.50(3 \mathrm{H}, \mathrm{s}, \mathrm{Tig}-\mathrm{H}-5), 8.15(2 \mathrm{H}, \mathrm{dd}, \mathrm{J}=7.8,1.3 \mathrm{~Hz}, \mathrm{Bz}-\mathrm{H}-3$, 7), $7.36(2 \mathrm{H}, \mathrm{dd}, J=7.8,7.4 \mathrm{~Hz}, \mathrm{Bz}-\mathrm{H}-4,6), 7.46(1 \mathrm{H}, \mathrm{t}, J=7.4 \mathrm{~Hz}$, $\mathrm{Bz}-\mathrm{H}-5), 4.76(1 \mathrm{H}, \mathrm{dd}, \mathrm{J}=9.4,1.5 \mathrm{~Hz}$, Ole- $\mathrm{H}-1), 1.71(1 \mathrm{H}, \mathrm{m}$, Ole$\mathrm{H}-2 \mathrm{a}), 2.39$ (1 H, m, Ole-H-2b), 3.56 (2 H, overlap, Ole-H-3,5), $3.55(1 \mathrm{H}$, overlap, Ole-H-4), $3.53(1 \mathrm{H}$, overlap, Ole-H-4), 1.56 $(3 \mathrm{H}, \mathrm{d}, J=5.3 \mathrm{~Hz}$, Ole- $\mathrm{H}-6), 3.48(3 \mathrm{H}, \mathrm{s}$, Ole-3-OCH $), 5.24(1 \mathrm{H}$, $\mathrm{d}, J=8.2 \mathrm{~Hz}$, Allo- $\mathrm{H}-1), 3.80(1 \mathrm{H}$, overlap, Allo- $\mathrm{H}-2), 4.39(1 \mathrm{H}, \mathrm{t}$, $J=2.7 \mathrm{~Hz}$, Allo-H-3), $3.66(1 \mathrm{H}, \mathrm{dd}, J=9.6,2.4 \mathrm{~Hz}$, Allo-H-4), 4.23 (1 H, m, Allo-H-5), $1.61(3 \mathrm{H}, \mathrm{d}, \mathrm{J}=6.2 \mathrm{~Hz}$, Allo-H-6), $3.79(1 \mathrm{H}, \mathrm{s}$, Allo-3-OCH $\left.{ }_{3}\right), 4.90\left(1 \mathrm{H}, \mathrm{d}, J=7.8 \mathrm{~Hz}, \mathrm{Glc}_{1}-\mathrm{H}-1\right), 3.99(1 \mathrm{H}, \mathrm{dd}$, $\left.J=8.2,7.8 \mathrm{~Hz}, \mathrm{Glc}_{1}-\mathrm{H}-2\right), 4.25\left(1 \mathrm{H}, \mathrm{m}, \mathrm{Glc}_{1}-\mathrm{H}-3\right), 4.28(1 \mathrm{H}, \mathrm{m}$, $\left.\mathrm{Glc}_{1}-\mathrm{H}-4\right), 3.93\left(1 \mathrm{H}, \mathrm{m}, \mathrm{Glc} \mathrm{c}_{1}-\mathrm{H}-5\right), 4.50\left(1 \mathrm{H}, \mathrm{m}, \mathrm{Glc}_{1}-\mathrm{H}-6 \mathrm{a}\right), 4.43$ $\left(1 \mathrm{H}, \mathrm{dd}, J=11.6 \mathrm{~Hz}, \mathrm{Glc}_{1}-\mathrm{H}-6 \mathrm{~b}\right), 5.19\left(1 \mathrm{H}, \mathrm{d}, J=7.9 \mathrm{~Hz}, \mathrm{Glc}_{2}-\mathrm{H}-1\right)$, $4.10\left(1 \mathrm{H}, \mathrm{dd}, J=8.2,7.9 \mathrm{~Hz} \mathrm{Glc}_{2}-\mathrm{H}-2\right), 4.20\left(1 \mathrm{H}, \mathrm{m}, \mathrm{Glc}_{2}-\mathrm{H}-3\right)$, $4.19\left(1 \mathrm{H}, \mathrm{m}, \mathrm{Glc}_{2}-\mathrm{H}-4\right), 4.01\left(1 \mathrm{H}, \mathrm{m}, \mathrm{Glc}_{2}-\mathrm{H}-5\right), 4.52(1 \mathrm{H}, \mathrm{d}$, $\left.J=11.4 \mathrm{~Hz}, \mathrm{Glc}_{2}-\mathrm{H}-6 \mathrm{a}\right), 4.30\left(1 \mathrm{H}, \mathrm{m}, \mathrm{Glc}_{2}-\mathrm{H}-6 \mathrm{~b}\right) .{ }^{13} \mathrm{C}$ NMR data $\left(150 \mathrm{MHz}\right.$, pyridine- $\left.d_{5}\right)$, see $>$ Tables 2 and 3.

Marstenacisside $B 11$ (2): white amorphous powder; $[\alpha]_{D}^{20}=$ $+23.7\left(c=0.038\right.$, pyridine). UV $(\mathrm{MeOH}) \lambda_{\max } 215.6(\varepsilon 14112) \mathrm{nm}$. $\mathrm{C}_{57} \mathrm{H}_{86} \mathrm{O}_{24}$, HRESIMS (positive): $\mathrm{m} / \mathrm{z} 1177.5454$ [M + Na] ${ }^{+}$(calcd. for $\mathrm{C}_{57} \mathrm{H}_{86} \mathrm{O}_{24} \mathrm{Na}$ : 1177.5407). ${ }^{1} \mathrm{H}$ NMR data $(500 \mathrm{MHz}$, pyridine$\left.d_{5}\right)$ : $\delta 3.79(1 \mathrm{H}, \mathrm{m}, \mathrm{H}-3), 5.88(1 \mathrm{H}, \mathrm{t}, \mathrm{J}=10.2 \mathrm{~Hz}, \mathrm{H}-11), 5.44$ $(1 \mathrm{H}, \mathrm{d}, J=10.2 \mathrm{~Hz}, \mathrm{H}-12), 3.06(1 \mathrm{H}, \mathrm{dd}, J=11.2,6.2 \mathrm{~Hz}, \mathrm{H}-17)$, $1.49\left(3 \mathrm{H}, \mathrm{s}, 18-\mathrm{CH}_{3}\right), 1.54\left(3 \mathrm{H}, \mathrm{s}, 19-\mathrm{CH}_{3}\right), 2.10\left(3 \mathrm{H}, \mathrm{s}, 21-\mathrm{CH}_{3}\right)$, $6.95\left(1 \mathrm{H}, \mathrm{qq}, J=7.1,1.3 \mathrm{~Hz}, \operatorname{Tig}_{1}-\mathrm{H}-3\right), 1.57(3 \mathrm{H}, \mathrm{d}, J=7.1 \mathrm{~Hz}$, $\left.\mathrm{Tig}_{1}-\mathrm{H}-4\right), 1.78\left(3 \mathrm{H}, \mathrm{s}, \mathrm{Tig}_{1}-\mathrm{H}-5\right), 6.93(1 \mathrm{H}, \mathrm{qq}, J=7.1,1.3 \mathrm{~Hz}$, $\left.\mathrm{Tig}_{2}-\mathrm{H}-3\right), 1.57\left(3 \mathrm{H}, \mathrm{d}, J=7.1 \mathrm{~Hz}, \mathrm{Tig}_{2}-\mathrm{H}-4\right), 1.84\left(3 \mathrm{H}, \mathrm{s}, \mathrm{Tig}_{2}-\right.$ $\mathrm{H}-5), 4.77\left(1 \mathrm{H}, \mathrm{d}, \mathrm{J}=9.7 \mathrm{~Hz}\right.$, Ole-H-1), $3.50\left(3 \mathrm{H}, \mathrm{s}\right.$, Ole-3- $\left.\mathrm{OCH}_{3}\right)$,
$5.27(1 \mathrm{H}, \mathrm{d}, \mathrm{J}=8.1 \mathrm{~Hz}$, Allo- $\mathrm{H}-1), 3.81(1 \mathrm{H}, \mathrm{s}, \text { Allo-3-OCH })_{3}, 4.92$ $\left(1 \mathrm{H}, \mathrm{d}, J=7.8 \mathrm{~Hz}, \mathrm{Glc}_{1}-\mathrm{H}-1\right), 5.22\left(1 \mathrm{H}, \mathrm{d}, J=7.9 \mathrm{~Hz}, \mathrm{Glc}_{2}-\mathrm{H}-1\right) .{ }^{13} \mathrm{C}$ NMR data $\left(125 \mathrm{MHz}\right.$, pyridine- $\left.d_{5}\right)$, see $>$ Tables 2 and $\mathbf{3}$.

Marstenacisside A8 (3): white amorphous powder; $[\alpha]_{D}^{20}=+10.8$ ( $c=0.051$, pyridine). UV (MeOH) $\lambda_{\max } 225.6$ ( $\varepsilon$ 22516) nm. $\mathrm{C}_{53} \mathrm{H}_{74} \mathrm{O}_{19}$, HRESIMS (negative): $\mathrm{m} / \mathrm{z} 1013.4787$ [M - H] ${ }^{-}$(calcd. for $\mathrm{C}_{53} \mathrm{H}_{73} \mathrm{O}_{19}$ : 1013.4746). ${ }^{1} \mathrm{H}$ NMR data $\left(500 \mathrm{MHz}\right.$, pyridine- $\left.d_{5}\right)$ :

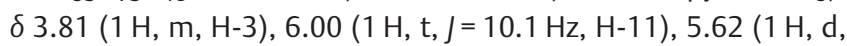
$J=10.1 \mathrm{~Hz}, \mathrm{H}-12), 3.11(1 \mathrm{H}, \mathrm{dd}, J=11.5,6.2 \mathrm{~Hz}, \mathrm{H}-17), 1.57(3 \mathrm{H}$, s, $\left.18-\mathrm{CH}_{3}\right), 1.56\left(3 \mathrm{H}, \mathrm{s}, 19-\mathrm{CH}_{3}\right), 2.01\left(3 \mathrm{H}, \mathrm{s}, 21-\mathrm{CH}_{3}\right), 6.79(1 \mathrm{H}$, q, J = 7.1 Hz, Tig-H-3), $1.35(3 \mathrm{H}, \mathrm{d}, J=7.0 \mathrm{~Hz}, \mathrm{Tig}-\mathrm{H}-4), 1.52(3 \mathrm{H}$, s, Tig-H-5), $8.18(2 \mathrm{H}, \mathrm{d}, J=7.9 \mathrm{~Hz}, \mathrm{Bz}-\mathrm{H}-3,7), 7.38(2 \mathrm{H}, \mathrm{dd}$, $J=7.9,7.4 \mathrm{~Hz}, \mathrm{Bz}-\mathrm{H}-4,6), 7.48(1 \mathrm{H}, \mathrm{t}, J=7.4 \mathrm{~Hz}, \mathrm{Bz}-\mathrm{H}-5), 4.78$ $(1 \mathrm{H}, \mathrm{d}, \mathrm{J}=9.4 \mathrm{~Hz}$, Ole-H-1), $1.74(1 \mathrm{H}, \mathrm{m}$, Ole-H-2a), $2.46(1 \mathrm{H}$, m, Ole-H-2b), 3.58 (2 H, overlap, Ole-H-3, 5), 3.57 (1 H, overlap, Ole-H-4), $3.55(1 \mathrm{H}$, overlap, Ole- $\mathrm{H}-4), 1.59(3 \mathrm{H}, \mathrm{d}, J=4.9 \mathrm{~Hz}$, Ole-H-6), $3.51\left(3 \mathrm{H}\right.$, s, Ole-3- $\left.\mathrm{OCH}_{3}\right), 5.27(1 \mathrm{H}, \mathrm{d}, \mathrm{J}=8.0 \mathrm{~Hz}$, Allo$\mathrm{H}-1), 3.81$ (1 H, overlap, Allo-H-2), 4.48 (1 H, br s, Allo-H-3), 3.75 $(1 \mathrm{H}, \mathrm{dd}, \mathrm{J}=9.6,2.0 \mathrm{~Hz}$, Allo-H-4), $4.27(1 \mathrm{H}, \mathrm{m}$, Allo-H-5), 1.61 (3 H, d, J = 6.1, Allo-H-6), $3.83\left(1 \mathrm{H}, \mathrm{s}\right.$, Allo-3-OCH $\left.\mathrm{CH}_{3}\right), 4.99(1 \mathrm{H}, \mathrm{d}$, $\left.J=7.7 \mathrm{~Hz}, \mathrm{Glc}_{1}-\mathrm{H}-1\right), 4.04(1 \mathrm{H}, \mathrm{dd}, J=8.2,7.8 \mathrm{~Hz}, \mathrm{Glc}-\mathrm{H}-2), 4.25$ (1 H, m, Glc-H-3), 4.23 (1 H, m, Glc-H-4), 4.00 (1 H, m, Glc-H-5), 4.55 (1 H, m, Glc-H-6a), 4.39 ( $1 \mathrm{H}, \mathrm{br} \mathrm{d}, \mathrm{J}=11.6 \mathrm{~Hz}$, Glc-H-6b). ${ }^{13} \mathrm{C}$ NMR (125 MHz, pyridine- $\left.d_{5}\right)$, data see $>$ Tables 2 and 3.

Marstenacisside $B 12$ (4): white amorphous powder; $[\alpha]_{D}^{20}=$ +34.4 ( $c=0.0465$, pyridine). UV (MeOH) $\lambda_{\max } 225.0$ ( $\varepsilon$ 13750) nm. $\mathrm{C}_{59} \mathrm{H}_{86} \mathrm{O}_{24}$, HRESIMS (negative): $\mathrm{m} / \mathrm{z} 1177.5488[\mathrm{M}-\mathrm{H}]^{-}$ (calcd. for $\mathrm{C}_{59} \mathrm{H}_{85} \mathrm{O}_{24}$ : 1177.5431). ${ }^{1} \mathrm{H}$ NMR data $(600 \mathrm{MHz}$, pyridine- $\left.d_{5}\right)$ : $\delta 3.84(1 \mathrm{H}, \mathrm{m}, \mathrm{H}-3), 5.84(1 \mathrm{H}, \mathrm{t}, J=10.2 \mathrm{~Hz}, \mathrm{H}-11), 5.52$ $(1 \mathrm{H}, \mathrm{d}, \mathrm{J}=9.9 \mathrm{~Hz}, \mathrm{H}-12), 3.07(1 \mathrm{H}, \mathrm{dd}, J=11.7,6.3 \mathrm{~Hz}, \mathrm{H}-17), 1.53$ $\left(3 \mathrm{H}, \mathrm{s}, 18-\mathrm{CH}_{3}\right), 1.26\left(3 \mathrm{H}, \mathrm{s}, 19-\mathrm{CH}_{3}\right), 2.00\left(3 \mathrm{H}, \mathrm{s}, 21-\mathrm{CH}_{3}\right), 6.74$ $(1 \mathrm{H}, \mathrm{qq}, \mathrm{J}=7.1,1.2 \mathrm{~Hz}$, Tig-H-3), $1.34(3 \mathrm{H}, \mathrm{d}, J=7.1 \mathrm{~Hz}, \mathrm{Tig}-\mathrm{H}-4)$, 1.52 ( $3 \mathrm{H}, \mathrm{s}, \mathrm{Tig}-\mathrm{H}-5), 8.14(2 \mathrm{H}, \mathrm{dd}, \mathrm{J}=8.0,1.2 \mathrm{~Hz}, \mathrm{Bz}-\mathrm{H}-3,7), 7.35$ ( $2 \mathrm{H}, \mathrm{dd}, J=7.8,7.2 \mathrm{~Hz}, \mathrm{Bz}-\mathrm{H}-4,6), 7.46(1 \mathrm{H}, \mathrm{t}, J=7.2 \mathrm{~Hz}, \mathrm{Bz}-\mathrm{H}-5)$, $4.77\left(1 \mathrm{H}, \mathrm{br} \mathrm{d}, \mathrm{J}=9.2 \mathrm{~Hz}\right.$, Ole-H-1), $3.49\left(3 \mathrm{H}, \mathrm{s}\right.$, Ole-3-OCH $\left.{ }_{3}\right), 5.26$ $(1 \mathrm{H}, \mathrm{d}, \mathrm{J}=8.1 \mathrm{~Hz}$, Allo-H-1), $3.79(1 \mathrm{H}, \mathrm{s}$, Allo-3-OCH 3$), 4.92(1 \mathrm{H}$, $\left.\mathrm{d}, J=7.7 \mathrm{~Hz}, \mathrm{Glc}_{1}-\mathrm{H}-1\right), 5.19\left(1 \mathrm{H}, \mathrm{d}, J=7.8 \mathrm{~Hz}, \mathrm{Glc}_{2}-\mathrm{H}-1\right) .{ }^{13} \mathrm{C} \mathrm{NMR}$ data $\left(125 \mathrm{MHz}\right.$, pyridine- $\left.d_{5}\right)$, see $\mathbf{T a b l e s} \mathbf{2}$ and $\mathbf{3}$.

Marstenacisside $B 13$ (7): white amorphous powder; $[\alpha]_{\mathrm{D}}^{25}=$ $+35.8\left(c=0.0608\right.$, MeOH). UV (MeOH) $\lambda_{\max } 225.4(\varepsilon 13167) \mathrm{nm}$. $\mathrm{C}_{59} \mathrm{H}_{88} \mathrm{O}_{25}$, HRESIMS (negative): $\mathrm{m} / \mathrm{z} 1195.5596[\mathrm{M}-\mathrm{H}]^{-}$(calcd. for $\mathrm{C}_{59} \mathrm{H}_{87} \mathrm{O}_{25}$ : 1195.5536). ${ }^{1} \mathrm{H}$ NMR data $\left(500 \mathrm{MHz}\right.$, pyridine- $\left.d_{5}\right)$ :

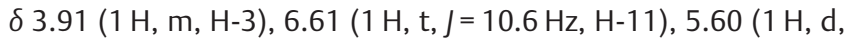
$J=10.0 \mathrm{~Hz}, \mathrm{H}-12), 3.35(1 \mathrm{H}, \mathrm{dd}, J=9.0,5.2 \mathrm{~Hz}, \mathrm{H}-17), 1.72(3 \mathrm{H}, \mathrm{s}$, $\left.18-\mathrm{CH}_{3}\right), 1.53\left(3 \mathrm{H}, \mathrm{s}, 19-\mathrm{CH}_{3}\right), 2.06\left(3 \mathrm{H}, \mathrm{s}, 21-\mathrm{CH}_{3}\right), 6.82(1 \mathrm{H}, \mathrm{q}$, $J=7.1 \mathrm{~Hz}$, Tig-H-3), $1.38(3 \mathrm{H}, \mathrm{d}, J=7.1 \mathrm{~Hz}, \mathrm{Tig}-\mathrm{H}-4), 1.54(3 \mathrm{H}, \mathrm{s}$, Tig-H-5), 8.26 (2 H, d, J = 7.6 Hz Bz-H-3, 7), $7.42(2 \mathrm{H}, \mathrm{t}, J=7.7 \mathrm{~Hz}$, $\mathrm{Bz}-\mathrm{H}-4,6), 7.51(1 \mathrm{H}, \mathrm{t}, J=7.4 \mathrm{~Hz}, \mathrm{Bz}-\mathrm{H}-5), 4.81(1 \mathrm{H}, \mathrm{br} \mathrm{d}$, $J=9.6 \mathrm{~Hz}$, Ole-H-1), $3.49\left(3 \mathrm{H}, \mathrm{s}\right.$, Ole-3-OCH $\left.{ }_{3}\right), 5.28(1 \mathrm{H}, \mathrm{d}$, $J=8.0 \mathrm{~Hz}$, Allo- $\mathrm{H}-1), 3.81\left(1 \mathrm{H}, \mathrm{s}\right.$, Allo-3-OCH $\left.\mathrm{OCH}_{3}\right), 4.92(1 \mathrm{H}, \mathrm{d}$, $\left.J=7.7 \mathrm{~Hz}, \mathrm{Glc}_{1}-\mathrm{H}-1\right), 5.21\left(1 \mathrm{H}, \mathrm{d}, J=7.9 \mathrm{~Hz}, \mathrm{Glc}_{2}-\mathrm{H}-1\right) .{ }^{13} \mathrm{C}$ NMR data $\left(125 \mathrm{MHz}\right.$, pyridine- $\left.d_{5}\right)$, see $\boldsymbol{\sim}$ Tables 2 and $\mathbf{3}$.

Marstenacisside $B 14$ (8): white amorphous powder; $[\alpha]_{D}^{25}=$ $+29.7(c=0.0738, \mathrm{MeOH})$. UV $(\mathrm{MeOH}) \lambda_{\max } 225.4$ ( $\varepsilon$ 19513) nm. $\mathrm{C}_{59} \mathrm{H}_{88} \mathrm{O}_{25}$, HRESIMS (negative): $\mathrm{m} / \mathrm{z} 1195.5588[\mathrm{M}-\mathrm{H}]^{-}$(calcd. for $\mathrm{C}_{59} \mathrm{H}_{87} \mathrm{O}_{25}$ : 1195.5536). ${ }^{1} \mathrm{H}$ NMR data $\left(500 \mathrm{MHz}\right.$, pyridine- $\left.d_{5}\right)$ :

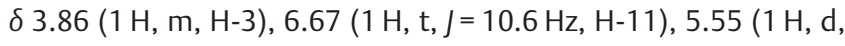


- Table $2{ }^{13} \mathrm{C}$ chemical shifts of the aglycones of $1-15$ (150 MHz for $1,4,6,11$, and 12 , and $125 \mathrm{MHz}$ for $2,3,5,7-10$, and $13-15$, pyridine- $\left.d_{5}\right)$.

\begin{tabular}{|c|c|c|c|c|c|c|c|c|c|c|c|c|c|}
\hline Position & 1 & 2 & 3 & 4 & 7 & 8 & 9 & 10 & 11 & 12 & 13 & 14 & 15 \\
\hline 1 & 38.8 & 38.7 & 38.8 & 37.7 & 39.6 & 39.6 & 39.6 & 39.6 & 38.8 & 38.8 & 38.8 & 38.1 & 38.3 \\
\hline 2 & 30.0 & 29.9 & 29.9 & 29.7 & 30.0 & 29.9 & 30.0 & 29.9 & 30.4 & 30.4 & 30.3 & 30.3 & 30.3 \\
\hline 3 & 77.0 & 77.0 & 76.9 & 76.0 & 76.3 & 76.2 & 76.3 & 76.2 & 77.3 & 77.3 & 77.2 & 76.2 & 76.1 \\
\hline 4 & 39.6 & 39.6 & 39.6 & 35.0 & 35.7 & 35.7 & 35.7 & 35.7 & 39.8 & 39.8 & 39.8 & 35.5 & 35.4 \\
\hline 5 & 141.5 & 141.5 & 141.5 & 44.2 & 45.8 & 45.7 & 45.7 & 45.7 & 139.7 & 139.8 & 139.7 & 44.7 & 44.7 \\
\hline 6 & 119.6 & 119.6 & 119.6 & 27.4 & 25.4 & 25.4 & 25.4 & 25.4 & 122.6 & 122.5 & 122.6 & 29.4 & 29.4 \\
\hline 7 & 33.1 & 33.1 & 33.1 & 32.5 & 35.2 & 35.2 & 35.2 & 35.2 & 28.2 & 28.3 & 28.3 & 28.4 & 28.4 \\
\hline 8 & 64.3 & 64.2 & 64.3 & 66.3 & 78.4 & 78.5 & 78.4 & 78.5 & 37.5 & 37.6 & 37.7 & 40.0 & 40.3 \\
\hline 9 & 49.7 & 49.7 & 49.6 & 52.5 & 51.4 & 51.5 & 51.4 & 51.5 & 47.9 & 48.1 & 48.1 & 50.1 & 50.3 \\
\hline 10 & 40.4 & 40.4 & 40.4 & 39.7 & 38.5 & 38.5 & 38.5 & 38.5 & 39.5 & 39.5 & 39.5 & 37.8 & 38.0 \\
\hline 11 & 68.7 & 68.7 & 68.7 & 68.5 & 71.3 & 72.2 & 71.3 & 72.2 & 71.8 & 71.9 & 72.7 & 71.6 & 71.7 \\
\hline 12 & 79.9 & 79.1 & 79.8 & 80.1 & 79.8 & 78.8 & 79.8 & 78.8 & 78.6 & 77.7 & 77.6 & 79.1 & 79.1 \\
\hline 13 & 47.4 & 47.5 & 47.4 & 47.5 & 55.8 & 55.7 & 55.8 & 55.7 & 54.9 & 54.9 & 54.9 & 55.0 & 55.0 \\
\hline 14 & 70.9 & 70.8 & 70.8 & 71.7 & 85.6 & 85.6 & 85.6 & 85.6 & 84.1 & 84.2 & 84.2 & 83.9 & 84.0 \\
\hline 15 & 28.3 & 28.4 & 28.3 & 28.2 & 36.3 & 36.4 & 36.3 & 36.4 & 34.6 & 34.8 & 34.8 & 33.9 & 34.0 \\
\hline 16 & 26.5 & 26.5 & 26.5 & 26.4 & 24.8 & 24.8 & 24.8 & 24.8 & 24.0 & 24.1 & 24.1 & 24.3 & 24.4 \\
\hline 17 & 61.4 & 61.3 & 61.4 & 61.3 & 59.5 & 59.4 & 59.5 & 59.4 & 58.3 & 58.3 & 58.3 & 58.4 & 58.4 \\
\hline 18 & 11.9 & 11.9 & 11.9 & 11.9 & 14.1 & 14.1 & 14.1 & 14.1 & 11.7 & 11.7 & 11.7 & 11.9 & 11.9 \\
\hline 19 & 19.2 & 19.2 & 19.2 & 13.1 & 13.5 & 13.5 & 13.5 & 13.5 & 19.3 & 19.3 & 19.4 & 12.4 & 12.4 \\
\hline 20 & 207.8 & 208.0 & 207.8 & 207.8 & 213.9 & 214.0 & 214.0 & 214.0 & 213.5 & 213.7 & 213.8 & 213.4 & 213.4 \\
\hline 21 & 31.3 & 31.4 & 31.3 & 31.2 & 31.8 & 31.8 & 31.8 & 31.8 & 31.8 & 31.8 & 31.8 & 31.7 & 31.7 \\
\hline 11-O- & Tig & $\mathrm{Tig}_{1}$ & Tig & Tig & Tig & $\mathrm{Bz}$ & Tig & $\mathrm{Bz}$ & Ac & $\mathrm{Tig}_{1}$ & $\mathrm{Bz}$ & $A C$ & Tig \\
\hline 1 & 167.0 & 167.0 & 167.0 & 167.2 & 167.1 & 166.0 & 167.1 & 166.0 & 170.2 & 167.1 & 166.1 & 170.4 & 167.4 \\
\hline 2 & 128.6 & 128.9 & 128.6 & 128.8 & 129.0 & 131.0 & 129.0 & 131.0 & 21.3 & 129.0 & 130.8 & 21.3 & 128.9 \\
\hline 3 & 138.7 & 138.6 & 138.8 & 138.5 & 138.6 & 130.1 & 138.6 & 130.1 & & 138.5 & 130.1 & & 138.6 \\
\hline 4 & 14.1 & 14.2 & 14.1 & 14.1 & 14.1 & 128.8 & 14.1 & 128.8 & & 14.3 & 128.8 & & 14.1 \\
\hline 5 & 11.7 & 12.0 & 11.7 & 11.7 & 11.8 & 133.3 & 11.8 & 133.3 & & 12.0 & 133.5 & & 11.7 \\
\hline 6 & & & & & & 128.8 & & 128.8 & & & 128.8 & & \\
\hline 7 & & & & & & 130.1 & & 130.1 & & & 130.1 & & \\
\hline $12-0-$ & $\mathrm{Bz}$ & $\mathrm{Tig}_{2}$ & $\mathrm{Bz}$ & $\mathrm{Bz}$ & $\mathrm{Bz}$ & Tig & $\mathrm{Bz}$ & Tig & $\mathrm{Bz}$ & $\mathrm{Tig}_{2}$ & Tig & $\mathrm{Bz}$ & $\mathrm{Bz}$ \\
\hline 1 & 166.5 & 167.5 & 166.5 & 166.5 & 166.9 & 168.0 & 166.9 & 168.0 & 166.8 & 167.9 & 167.8 & 166.8 & 166.8 \\
\hline 2 & 130.6 & 128.8 & 130.6 & 130.7 & 130.4 & 128.4 & 130.4 & 128.4 & 130.1 & 128.5 & 128.3 & 130.1 & 130.3 \\
\hline 3 & 130.0 & 138.4 & 130.0 & 130.0 & 130.1 & 138.5 & 130.1 & 138.5 & 130.2 & 138.7 & 138.8 & 130.2 & 130.1 \\
\hline 4 & 128.8 & 14.3 & 128.8 & 128.8 & 128.9 & 14.1 & 128.9 & 14.1 & 129.2 & 14.3 & 14.2 & 129.2 & 128.9 \\
\hline 5 & 133.5 & 12.0 & 133.5 & 133.4 & 133.6 & 11.8 & 133.6 & 11.8 & 134.0 & 12.1 & 11.9 & 133.9 & 133.7 \\
\hline 6 & 128.8 & & 128.8 & 128.8 & 128.9 & & 129.0 & & 129.2 & & & 129.2 & 128.9 \\
\hline 7 & 130.0 & & 130.0 & 130.0 & 130.1 & & 130.1 & & 130.2 & & & 130.2 & 130.1 \\
\hline
\end{tabular}

$J=10.0 \mathrm{~Hz}, \mathrm{H}-12), 3.30(1 \mathrm{H}, \mathrm{dd}, J=9.0,5.2 \mathrm{~Hz}, \mathrm{H}-17), 1.68(3 \mathrm{H}, \mathrm{s}$, $\left.18-\mathrm{CH}_{3}\right), 1.54\left(3 \mathrm{H}, \mathrm{s}, 19-\mathrm{CH}_{3}\right), 2.16\left(3 \mathrm{H}, \mathrm{s}, 21-\mathrm{CH}_{3}\right), 8.19(2 \mathrm{H}, \mathrm{d}$, $J=7.5 \mathrm{~Hz} \mathrm{Bz}-\mathrm{H}-3,7), 7.40(2 \mathrm{H}, \mathrm{dd}, J=7.7,7.2 \mathrm{~Hz}, \mathrm{Bz}-\mathrm{H}-4,6), 7.47$ $(1 \mathrm{H}, \mathrm{t}, J=7.2 \mathrm{~Hz}, \mathrm{Bz}-\mathrm{H}-5), 6.88(1 \mathrm{H}, \mathrm{q}, J=7.0 \mathrm{~Hz}, \mathrm{Tig}-\mathrm{H}-3), 1.40$ $(3 \mathrm{H}, \mathrm{d}, J=7.0 \mathrm{~Hz}$, Tig-H-4), $1.60(3 \mathrm{H}, \mathrm{s}, \mathrm{Tig}-\mathrm{H}-5), 4.78(1 \mathrm{H}, \mathrm{d}$, $J=9.5 \mathrm{~Hz}$, Ole-H-1), $3.48(3 \mathrm{H}, \mathrm{s} \text {, Ole-3-OCH })_{3}, 5.27(1 \mathrm{H}, \mathrm{d}$, $J=7.9 \mathrm{~Hz}$, Allo- $\mathrm{H}-1), 3.80(1 \mathrm{H}, \mathrm{s} \text {, Allo-3-OCH })_{3}, 4.92(1 \mathrm{H}, \mathrm{d}$, $\left.J=7.6 \mathrm{~Hz}, \mathrm{Glc}_{1}-\mathrm{H}-1\right), 5.21\left(1 \mathrm{H}, \mathrm{d}, J=7.8 \mathrm{~Hz}, \mathrm{Glc}_{2}-\mathrm{H}-1\right) .{ }^{13} \mathrm{C}$ NMR data (125 MHz, pyridine- $d_{5}$ ), see $>$ Tables 2 and 3.

Marstenacisside A9 (9): white amorphous powder; $[\alpha]_{\mathrm{D}}^{25}=+47.0$ $(c=0.0885, \mathrm{MeOH})$. UV $(\mathrm{MeOH}) \lambda_{\max } 225.0(\varepsilon$ 15189) nm.
$\mathrm{C}_{53} \mathrm{H}_{78} \mathrm{O}_{20}$, HRESIMS (negative): $\mathrm{m} / \mathrm{z} 1033.5083[\mathrm{M}-\mathrm{H}]^{-}$(calcd. for $\mathrm{C}_{53} \mathrm{H}_{77} \mathrm{O}_{20}$ : 1195.5048). ${ }^{1} \mathrm{H}$ NMR data $\left(500 \mathrm{MHz}\right.$, pyridine- $\left.d_{5}\right)$ : d $3.91(1 \mathrm{H}, \mathrm{m}, \mathrm{H}-3), 6.61(1 \mathrm{H}, \mathrm{t}, J=10.6 \mathrm{~Hz}, \mathrm{H}-11), 5.60(1 \mathrm{H}, \mathrm{d}$, $J=10.1 \mathrm{~Hz}, \mathrm{H}-12), 3.35(1 \mathrm{H}, \mathrm{dd}, J=9.0,5.2 \mathrm{~Hz}, \mathrm{H}-17), 1.72(3 \mathrm{H}, \mathrm{s}$, $\left.18-\mathrm{CH}_{3}\right), 1.53\left(3 \mathrm{H}, \mathrm{s}, 19-\mathrm{CH}_{3}\right), 2.06\left(3 \mathrm{H}, \mathrm{s}, 21-\mathrm{CH}_{3}\right), 6.82(1 \mathrm{H}, \mathrm{q}$, $J=7.1 \mathrm{~Hz}$, Tig-H-3), $1.38(3 \mathrm{H}, \mathrm{d}, J=7.1 \mathrm{~Hz}, \mathrm{Tig}-\mathrm{H}-4), 1.54(3 \mathrm{H}, \mathrm{s}$, Tig-H-5), $8.26(2 \mathrm{H}, \mathrm{d}, \mathrm{J}=7.6 \mathrm{~Hz}, \mathrm{Bz}-\mathrm{H}-3,7), 7.42(2 \mathrm{H}, \mathrm{t}, J=7.7 \mathrm{~Hz}$, $\mathrm{Bz}-\mathrm{H}-4,6), 7.51(1 \mathrm{H}, \mathrm{t}, J=7.4 \mathrm{~Hz}, \mathrm{Bz}-\mathrm{H}-5), 4.82(1 \mathrm{H}, \mathrm{d}, J=9.7 \mathrm{~Hz}$, Ole-H-1), $3.50\left(3 \mathrm{H}\right.$, s, Ole-3- $\left.\mathrm{OCH}_{3}\right), 5.29(1 \mathrm{H}, \mathrm{d}, J=8.1 \mathrm{~Hz}$, Allo$\mathrm{H}-1), 3.83\left(1 \mathrm{H}, \mathrm{s}\right.$, Allo-3-OCH $\mathrm{OCH}_{3}, 4.99(1 \mathrm{H}, \mathrm{d}, \mathrm{J}=7.7 \mathrm{~Hz}, \mathrm{Glc}-\mathrm{H}-1)$. ${ }^{13} \mathrm{C}$ NMR data (125 MHz, pyridine- $d_{5}$ ), see $\bullet$ Tables 2 and 3. 
- Table $3{ }^{13} \mathrm{C}$ chemical shifts of the sugar moieties of $1-15$ ( $150 \mathrm{MHz}$ for $1,4,6,11$, and 12 , and $125 \mathrm{MHz}$ for $2,3,5,7-10$, and $13-15$, pyridine- $d_{5}$ ).

\begin{tabular}{|c|c|c|c|c|c|c|c|c|c|c|c|c|c|}
\hline Position & 1 & 2 & 3 & 4 & 7 & 8 & 9 & 10 & 11 & 12 & 13 & 14 & 15 \\
\hline Ole-1 & 97.9 & 97.9 & 97.9 & 97.5 & 97.5 & 97.4 & 97.5 & 97.4 & 98.0 & 98.0 & 97.9 & 97.7 & 97.5 \\
\hline-2 & 37.7 & 37.7 & 37.8 & 37.8 & 37.8 & 37.8 & 37.8 & 37.8 & 37.8 & 37.8 & 37.8 & 37.8 & 37.8 \\
\hline-3 & 79.6 & 79.6 & 79.6 & 79.6 & 79.6 & 79.6 & 79.8 & 79.6 & 79.6 & 79.6 & 79.6 & 79.7 & 79.6 \\
\hline-4 & 83.2 & 83.2 & 83.2 & 83.2 & 83.3 & 83.2 & 83.3 & 83.2 & 83.3 & 83.2 & 83.2 & 83.3 & 83.3 \\
\hline-5 & 71.9 & 71.9 & 71.9 & 71.9 & 71.9 & 71.9 & 72.0 & 71.9 & 71.9 & 71.9 & 71.9 & 72.0 & 71.9 \\
\hline-6 & 19.0 & 19.0 & 19.0 & 19.0 & 19.0 & 19.0 & 19.1 & 19.1 & 19.0 & 19.0 & 19.0 & 19.1 & 19.0 \\
\hline $3-\mathrm{OCH}_{3}$ & 57.2 & 57.2 & 57.2 & 57.2 & 57.2 & 57.1 & 57.2 & 57.2 & 57.2 & 57.2 & 57.2 & 57.2 & 57.3 \\
\hline Allo-1 & 101.9 & 101.9 & 101.9 & 101.9 & 101.9 & 101.9 & 101.9 & 101.9 & 101.9 & 101.9 & 101.9 & 101.9 & 101.9 \\
\hline-2 & 72.7 & 72.7 & 72.7 & 72.7 & 72.7 & 72.7 & 72.7 & 72.7 & 72.7 & 72.7 & 72.8 & 72.7 & 72.7 \\
\hline-3 & 83.1 & 83.1 & 83.2 & 83.1 & 83.1 & 83.1 & 83.2 & 83.2 & 83.1 & 83.1 & 83.2 & 83.1 & 83.2 \\
\hline-4 & 83.4 & 83.4 & 83.3 & 83.4 & 83.4 & 83.4 & 83.4 & 83.3 & 83.4 & 83.4 & 83.3 & 83.4 & 83.3 \\
\hline-5 & 69.5 & 69.5 & 69.5 & 69.5 & 69.5 & 69.5 & 69.5 & 69.5 & 69.5 & 69.5 & 69.5 & 69.5 & 69.5 \\
\hline-6 & 18.3 & 18.3 & 18.3 & 18.3 & 18.3 & 18.3 & 18.3 & 18.3 & 18.3 & 18.3 & 18.3 & 18.3 & 18.3 \\
\hline $3-\mathrm{OCH}_{3}$ & 61.7 & 61.7 & 61.7 & 61.7 & 61.7 & 61.7 & 61.7 & 61.7 & 61.7 & 61.7 & 61.7 & 61.7 & 61.7 \\
\hline $\mathrm{Glc}_{1}-1$ & 106.6 & 106.6 & 106.6 & 106.2 & 106.2 & 106.2 & 106.6 & 106.6 & 106.2 & 106.2 & 106.6 & 106.2 & 106.6 \\
\hline-2 & 75.0 & 75.0 & 75.5 & 75.0 & 75.0 & 75.0 & 75.5 & 75.5 & 75.0 & 75.0 & 75.5 & 75.0 & 75.5 \\
\hline-3 & 76.6 & 76.6 & 78.4 & 76.6 & 76.6 & 76.6 & 78.4 & 78.4 & 76.6 & 76.6 & 78.4 & 76.6 & 78.4 \\
\hline-4 & 81.5 & 81.5 & 71.9 & 81.5 & 81.5 & 81.5 & 72.0 & 72.0 & 81.5 & 81.5 & 71.9 & 81.5 & 71.9 \\
\hline-5 & 76.4 & 76.4 & 78.4 & 76.4 & 76.4 & 76.4 & 78.4 & 78.4 & 76.4 & 76.4 & 78.4 & 76.4 & 78.4 \\
\hline-6 & 63.4 & 62.4 & 63.0 & 62.5 & 62.5 & 62.4 & 63.0 & 63.0 & 62.4 & 62.4 & 63.0 & 62.4 & 63.0 \\
\hline $\mathrm{Glc}_{2}-1$ & 105.0 & 105.0 & & 105.0 & 105.0 & 105.0 & & & 105.0 & 105.0 & & 105.0 & \\
\hline-2 & 74.8 & 74.8 & & 74.8 & 74.8 & 74.8 & & & 74.8 & 74.8 & & 74.8 & \\
\hline-3 & 78.3 & 78.3 & & 78.3 & 78.3 & 78.3 & & & 78.3 & 78.3 & & 78.3 & \\
\hline-4 & 71.6 & 71.6 & & 71.6 & 71.6 & 71.5 & & & 71.5 & 71.6 & & 71.6 & \\
\hline-5 & 78.6 & 78.6 & & 78.6 & 78.6 & 78.6 & & & 78.6 & 78.6 & & 78.6 & \\
\hline-6 & 62.5 & 62.5 & & 62.5 & 62.4 & 62.5 & & & 62.5 & 62.5 & & 62.5 & \\
\hline
\end{tabular}

Marstenacisside $A 10$ (10): white amorphous powder; $[\alpha]_{D}^{25}=$ $+35.3(c=0.0962, \mathrm{MeOH})$. UV $(\mathrm{MeOH}) \lambda_{\max } 225.2(\varepsilon$ 14777) nm. $\mathrm{C}_{53} \mathrm{H}_{78} \mathrm{O}_{20}$, HRESIMS (negative): $\mathrm{m} / \mathrm{z} 1033.5059$ [M - H] $]^{-}$(calcd. for $\mathrm{C}_{53} \mathrm{H}_{77} \mathrm{O}_{20}:$ 1033.5048). ${ }^{1} \mathrm{H}$ NMR data $\left(500 \mathrm{MHz}\right.$, pyridine- $\left.d_{5}\right)$ : d $3.87(1 \mathrm{H}, \mathrm{m}, \mathrm{H}-3), 6.67(1 \mathrm{H}, \mathrm{t}, J=10.7 \mathrm{~Hz}, \mathrm{H}-11), 5.55(1 \mathrm{H}, \mathrm{d}$, $J=10.1 \mathrm{~Hz}, \mathrm{H}-12), 3.29(1 \mathrm{H}, \mathrm{dd}, J=9.2,5.4 \mathrm{~Hz}, \mathrm{H}-17), 1.68(3 \mathrm{H}, \mathrm{s}$, $\left.18-\mathrm{CH}_{3}\right), 1.54\left(3 \mathrm{H}, \mathrm{s}, 19-\mathrm{CH}_{3}\right), 2.16\left(3 \mathrm{H}, \mathrm{s}, 21-\mathrm{CH}_{3}\right), 8.19(2 \mathrm{H}, \mathrm{d}$, $J=7.5 \mathrm{~Hz}, \mathrm{Bz}-\mathrm{H}-3,7), 7.41(2 \mathrm{H}, \mathrm{dd}, J=7.5,7.3 \mathrm{~Hz}, \mathrm{Bz}-\mathrm{H}-4,6), 7.47$ $(1 \mathrm{H}, \mathrm{t}, J=7.3 \mathrm{~Hz}, \mathrm{Bz}-\mathrm{H}-5), 6.88(1 \mathrm{H}, \mathrm{q}, J=7.0 \mathrm{~Hz}, \mathrm{Tig}-\mathrm{H}-3), 1.40$ $(3 \mathrm{H}, \mathrm{d}, J=7.0 \mathrm{~Hz}$, Tig-H-4), $1.60(3 \mathrm{H}, \mathrm{s}, \mathrm{Tig}-\mathrm{H}-5), 4.79(1 \mathrm{H}, \mathrm{d}$, $J=9.5 \mathrm{~Hz}$, Ole- $\mathrm{H}-1), 3.48(3 \mathrm{H}, \mathrm{s} \text {, Ole-3-OCH })_{3}, 5.27(1 \mathrm{H}, \mathrm{d}$, $J=8.2 \mathrm{~Hz}$, Allo- $\mathrm{H}-1), 3.83(1 \mathrm{H}, \mathrm{s} \text {, Allo-3-OCH })_{3}, 4.98(1 \mathrm{H}, \mathrm{d}$, $J=7.8 \mathrm{~Hz}$, Glc-H-1). ${ }^{13} \mathrm{C} \mathrm{NMR} \mathrm{data}\left(125 \mathrm{MHz}\right.$, pyridine- $\left.d_{5}\right)$, see

\section{- Tables 2 and 3.}

Marstenacisside B15 (11): white amorphous powder; $[\alpha]_{\mathrm{D}}^{25}=$ + $7.0\left(c=0.0938\right.$, MeOH). UV (MeOH) $\lambda_{\max } 230.4$ ( $\varepsilon$ 9408) nm. $\mathrm{C}_{56} \mathrm{H}_{82} \mathrm{O}_{24}$, HRESIMS (negative): $\mathrm{m} / \mathrm{z} 1137.5137$ [M $\left.-\mathrm{H}\right]^{-}$(calcd. for $\mathrm{C}_{56} \mathrm{H}_{81} \mathrm{O}_{24}$ : 1137.5118). ${ }^{1} \mathrm{H}$ NMR data $\left(600 \mathrm{MHz}\right.$, pyridine- $\left.d_{5}\right)$ :

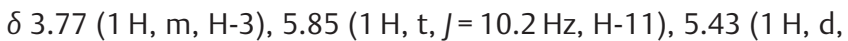
$J=10.2 \mathrm{~Hz}, \mathrm{H}-12), 3.23(1 \mathrm{H}, \mathrm{dd}, J=9.6,4.8 \mathrm{~Hz}, \mathrm{H}-17), 1.44(3 \mathrm{H}, \mathrm{s}$, $\left.18-\mathrm{CH}_{3}\right), 1.25\left(3 \mathrm{H}, \mathrm{s}, 19-\mathrm{CH}_{3}\right), 2.06\left(3 \mathrm{H}, \mathrm{s}, 21-\mathrm{CH}_{3}\right), 8.36(2 \mathrm{H}, \mathrm{d}$, $J=7.9 \mathrm{~Hz}, \mathrm{Bz}-\mathrm{H}-3,7), 7.49$ (2 H, dd, J= 7.9, 7.4 Hz, Bz-H-4, 6), 7.57
(1 H, overlap, Bz-H-5), $4.75(1 \mathrm{H}, \mathrm{d}, \mathrm{J}=9.2 \mathrm{~Hz}$, Ole- $\mathrm{H}-1), 3.49(3 \mathrm{H}$, s, Ole-3-OCH 3 ), $5.26(1 \mathrm{H}, \mathrm{d}, J=8.0 \mathrm{~Hz}$, Allo- $\mathrm{H}-1), 3.79(1 \mathrm{H}, \mathrm{s}, \mathrm{Al}-$ lo-3-OCH $)_{3}, 4.90\left(1 \mathrm{H}, \mathrm{d}, J=7.7 \mathrm{~Hz}, \mathrm{Glc}_{1}-\mathrm{H}-1\right), 5.19(1 \mathrm{H}, \mathrm{d}$, $\left.J=7.8 \mathrm{~Hz}, \mathrm{Glc}_{2}-\mathrm{H}-1\right) .{ }^{13} \mathrm{C}$ NMR data $\left(150 \mathrm{MHz}\right.$, pyridine- $\left.d_{5}\right)$, see

\section{- Tables 2 and 3.}

Marstenacisside B16 (12): white amorphous powder; $[\alpha]_{D}^{25}=$ $+41.6(c=0.0608, \mathrm{MeOH})$. UV $(\mathrm{MeOH}) \lambda_{\max } 215.2$ ( $\varepsilon$ 17679) nm. $\mathrm{C}_{57} \mathrm{H}_{88} \mathrm{O}_{24}$, HRESIMS (negative): $\mathrm{m} / \mathrm{z} 1155.5636$ [M $\left.-\mathrm{H}\right]^{-}$(calcd. for $\mathrm{C}_{57} \mathrm{H}_{87} \mathrm{O}_{24}$ : 1155.5587). ${ }^{1} \mathrm{H}$ NMR data $\left(600 \mathrm{MHz}\right.$, pyridine- $\left.d_{5}\right)$ : d $3.76(1 \mathrm{H}, \mathrm{m}, \mathrm{H}-3), 5.88(1 \mathrm{H}, \mathrm{t}, J=10.4 \mathrm{~Hz}, \mathrm{H}-11), 5.29(1 \mathrm{H}, \mathrm{d}$, $J=10.0 \mathrm{~Hz}, \mathrm{H}-12), 3.18(1 \mathrm{H}, \mathrm{dd}, J=9.3,4.8 \mathrm{~Hz}, \mathrm{H}-17), 1.38(3 \mathrm{H}, \mathrm{s}$, $\left.18-\mathrm{CH}_{3}\right), 1.31\left(3 \mathrm{H}, \mathrm{s}, 19-\mathrm{CH}_{3}\right), 2.17\left(3 \mathrm{H}, \mathrm{s}, 21-\mathrm{CH}_{3}\right), 6.92(1 \mathrm{H}$, qq, J= 7.1, $\left.1.4 \mathrm{~Hz}, \mathrm{Tig}_{1}-\mathrm{H}-3\right), 1.57\left(3 \mathrm{H}, \mathrm{d}, J=7.1 \mathrm{~Hz}, \mathrm{Tig}_{1}-\mathrm{H}-4\right)$, $1.78\left(3 \mathrm{H}, \mathrm{s}, \mathrm{Tig}_{1}-\mathrm{H}-5\right), 7.06\left(1 \mathrm{H}, \mathrm{qq}, J=7.1,1.3 \mathrm{~Hz}, \operatorname{Tig}_{2}-\mathrm{H}-3\right)$, $1.64\left(3 \mathrm{H}, \mathrm{d}, J=7.1 \mathrm{~Hz}, \mathrm{Tig}_{2}-\mathrm{H}-4\right), 1.89\left(3 \mathrm{H}, \mathrm{s}, \mathrm{Tig}_{2}-\mathrm{H}-5\right), 4.74$ $(1 \mathrm{H}$, br $\mathrm{d}, J=9.2 \mathrm{~Hz}$, Ole-H-1), $3.48(3 \mathrm{H}, \mathrm{s}$, Ole-3-OCH$), 5.24$ $(1 \mathrm{H}, \mathrm{d}, J=8.1 \mathrm{~Hz}$, Allo- $\mathrm{H}-1), 3.79(1 \mathrm{H}, \mathrm{s}$, Allo-3-OCH 3$), 4.90(1 \mathrm{H}$, $\left.\mathrm{d}, J=7.7 \mathrm{~Hz}, \mathrm{Glc}_{1}-\mathrm{H}-1\right), 5.19\left(1 \mathrm{H}, \mathrm{d}, J=7.8 \mathrm{~Hz}, \mathrm{Glc}_{2}-\mathrm{H}-1\right) .{ }^{13} \mathrm{C} \mathrm{NMR}$ data $\left(150 \mathrm{MHz}\right.$, pyridine- $\left.d_{5}\right)$, see $>$ Tables 2 and 3.

Marstenacisside $A 11$ (13): white amorphous powder; $[\alpha]_{D}^{25}=$ $+51.7(c=0.0769, \mathrm{MeOH})$. UV $(\mathrm{MeOH}) \lambda_{\max } 225.8(\varepsilon 14318) \mathrm{nm}$. $\mathrm{C}_{53} \mathrm{H}_{76} \mathrm{O}_{19}$, HRESIMS (negative): $\mathrm{m} / \mathrm{z} 1015.4949[\mathrm{M}-\mathrm{H}]^{-}$(calcd. 
for $\mathrm{C}_{53} \mathrm{H}_{75} \mathrm{O}_{19}$ : 1015.4903). ${ }^{1} \mathrm{H}$ NMR data (500 MHz, pyridine- $\left.d_{5}\right): \delta$ $3.75(1 \mathrm{H}, \mathrm{m}, \mathrm{H}-3), 6.08(1 \mathrm{H}, \mathrm{t}, J=10.2 \mathrm{~Hz}, \mathrm{H}-11), 5.44(1 \mathrm{H}, \mathrm{d}$, $J=10.0 \mathrm{~Hz}, \mathrm{H}-12), 3.22(1 \mathrm{H}, \mathrm{dd}, J=9.4,4.7 \mathrm{~Hz}, \mathrm{H}-17), 1.37(3 \mathrm{H}, \mathrm{s}$, $\left.18-\mathrm{CH}_{3}\right), 1.25\left(3 \mathrm{H}, \mathrm{s}, 19-\mathrm{CH}_{3}\right), 2.18\left(3 \mathrm{H}, \mathrm{s}, 21-\mathrm{CH}_{3}\right), 8.16(2 \mathrm{H}, \mathrm{d}$, $J=7.8 \mathrm{~Hz} \mathrm{Bz-H}-3,7), 7.38(2 \mathrm{H}, \mathrm{dd}, J=7.8,7.4 \mathrm{~Hz}, \mathrm{Bz}-\mathrm{H}-4,6), 7.48$ $(1 \mathrm{H}, J=7.6, \mathrm{Bz}-\mathrm{H}-5), 6.92(1 \mathrm{H}, \mathrm{q}, J=7.0 \mathrm{~Hz}, \mathrm{Tig}-\mathrm{H}-3), 1.46(3 \mathrm{H}, \mathrm{d}$, $J=7.0 \mathrm{~Hz}$, Tig-H-4), $1.66(3 \mathrm{H}, \mathrm{s}, \mathrm{Tig}-\mathrm{H}-5), 4.72(1 \mathrm{H}, \mathrm{brd}, J=9.5 \mathrm{~Hz}$, Ole-H-1), $3.50(3 \mathrm{H}, \mathrm{s}$, Ole-3-OCH $), 5.25(1 \mathrm{H}, \mathrm{d}, J=8.0 \mathrm{~Hz}$, Allo$\mathrm{H}-1), 3.82(1 \mathrm{H}, \mathrm{s}$, Allo-3-OCH 3$), 4.98(1 \mathrm{H}, \mathrm{d}, J=7.7 \mathrm{~Hz}, \mathrm{Glc}-\mathrm{H}-1)$. ${ }^{13} \mathrm{C}$ NMR data $\left(125 \mathrm{MHz}\right.$, pyridine- $\left.d_{5}\right)$, see $>$ Tables 2 and 3.

Marstenacisside $B 17$ (14): white amorphous powder; $[\alpha]_{D}^{25}=$ $+8.2(c=0.0500, \mathrm{MeOH})$. UV $(\mathrm{MeOH}) \lambda_{\max } 230.4(\varepsilon 16817) \mathrm{nm}$. $\mathrm{C}_{56} \mathrm{H}_{84} \mathrm{O}_{24}$, HRESIMS (negative): $\mathrm{m} / \mathrm{z} 1139.5333$ [M - H] ${ }^{-}$(calcd. for $\mathrm{C}_{56} \mathrm{H}_{83} \mathrm{O}_{24}$ : 1139.5274). ${ }^{1} \mathrm{H}$ NMR data (500 MHz, pyridine- $\left.d_{5}\right)$ :

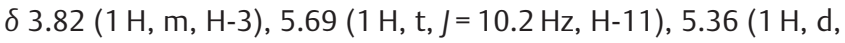
$J=9.8 \mathrm{~Hz}, \mathrm{H}-12), 3.22(1 \mathrm{H}, \mathrm{dd}, J=8.8,5.0 \mathrm{~Hz}, \mathrm{H}-17), 1.41(3 \mathrm{H}, \mathrm{s}$, $\left.18-\mathrm{CH}_{3}\right), 0.99\left(3 \mathrm{H}, \mathrm{s}, 19-\mathrm{CH}_{3}\right), 2.05\left(3 \mathrm{H}, \mathrm{s}, 21-\mathrm{CH}_{3}\right), 8.35(2 \mathrm{H}, \mathrm{d}$, $J=7.9 \mathrm{~Hz}, \mathrm{Bz}-\mathrm{H}-3,7), 7.49$ (2 H, dd, J= 7.9, 7.4 Hz, Bz-H-4, 6), 7.57 ( $1 \mathrm{H}$, overlap, Bz-H-5), $4.77(1 \mathrm{H}$, br d, J=9.2 Hz, Ole- $\mathrm{H}-1), 3.50$ $\left(3 \mathrm{H}, \mathrm{s}\right.$, Ole-3-OCH $\left.\mathrm{OCH}_{3}\right), 2.27(1 \mathrm{H}, \mathrm{d}, \mathrm{J}=8.1 \mathrm{~Hz}$, Allo-H-1), $3.79(1 \mathrm{H}$, s, Allo-3-OCH $)_{3}, 4.90\left(1 \mathrm{H}, \mathrm{d}, J=7.7 \mathrm{~Hz}, \mathrm{Glc}_{1}-\mathrm{H}-1\right), 5.19(1 \mathrm{H}, \mathrm{d}$, $\left.J=7.8 \mathrm{~Hz}, \mathrm{Glc}_{2}-\mathrm{H}-1\right) .{ }^{13} \mathrm{C}$ NMR data $\left(125 \mathrm{MHz}\right.$, pyridine- $\left.d_{5}\right)$, see - Tables 2 and 3.

Marstenacisside $A 12$ (15): white amorphous powder; $[\alpha]_{D}^{25}=$ + $37.6\left(c=0.0792\right.$, MeOH). UV (MeOH) $\lambda_{\max } 225.2$ ( $\left.\varepsilon 20064\right) \mathrm{nm}$. $\mathrm{C}_{53} \mathrm{H}_{78} \mathrm{O}_{19}$, HRESIMS (negative): $\mathrm{m} / \mathrm{z} 1017.5085$ [M - H] ${ }^{-}$(calcd. for $\mathrm{C}_{53} \mathrm{H}_{77} \mathrm{O}_{19}$ : 1017.5059). ${ }^{1} \mathrm{H}$ NMR data $\left(500 \mathrm{MHz}\right.$, pyridine- $\left.d_{5}\right)$ :

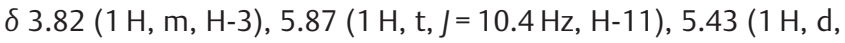
$J=9.9 \mathrm{~Hz}, \mathrm{H}-12), 3.28(1 \mathrm{H}, \mathrm{dd}, J=9.1,5.0 \mathrm{~Hz}, \mathrm{H}-17), 1.46(3 \mathrm{H}, \mathrm{s}$, $\left.18-\mathrm{CH}_{3}\right), 1.07\left(3 \mathrm{H}, \mathrm{s}, 19-\mathrm{CH}_{3}\right), 2.08\left(3 \mathrm{H}, \mathrm{s}, 21-\mathrm{CH}_{3}\right), 6.78(1 \mathrm{H}, \mathrm{q}$, $J=7.1 \mathrm{~Hz}$, Tig-H-3), $1.40(3 \mathrm{H}, \mathrm{d}, J=7.1 \mathrm{~Hz}, \mathrm{Tig}-\mathrm{H}-4), 1.54(3 \mathrm{H}, \mathrm{s}$, Tig-H-5), 8.27 (2 H, d, J = 7.7 Hz, Bz-H-3, 7), 7.45 (2 H, dd, J = 7.7, $7.5 \mathrm{~Hz}, \mathrm{Bz}-\mathrm{H}-4,6), 7.53(1 \mathrm{H}, \mathrm{t}, \mathrm{J}=7.4 \mathrm{~Hz}, \mathrm{Bz}-\mathrm{H}-5), 4.77(1 \mathrm{H}$, br d, $J=9.7 \mathrm{~Hz}$, Ole-H-1), $3.50(3 \mathrm{H}, \mathrm{s} \text {, Ole-3-OCH })_{3}, 5.27(1 \mathrm{H}, \mathrm{d}$, $J=8.0 \mathrm{~Hz}$, Allo- $\mathrm{H}-1), 3.80(1 \mathrm{H}, \mathrm{s}, \text { Allo-3-OCH })_{3}, 4.98(1 \mathrm{H}, \mathrm{d}$, $J=7.8 \mathrm{~Hz}$, Glc-H-1). ${ }^{13} \mathrm{C} \mathrm{NMR}$ data $\left(125 \mathrm{MHz}\right.$, pyridine- $\left.d_{5}\right)$, see

- Tables 2 and 3.

\section{HIV inhibition assay}

SupT1 cells $\left(2 \times 10^{5}\right)$ were co-transfected with $0.6 \mathrm{mg}$ of pNL-LucE and $0.4 \mathrm{mg}$ of $\mathrm{pHIT} / \mathrm{G}$. Then the VSV-G pseudo-typed viral supernatant (HIV-1) was harvested by filtration through a $0.45-\mu \mathrm{m}$ filter after $48 \mathrm{~h}$ and the concentration of viral capsid protein was determined by p24 antigen capture ELISA (Biomerieux). SupT1 cells were exposed to VSV-G pseudo-typed HIV-1 $(\mathrm{MOI}=1)$ at $37.8^{\circ} \mathrm{C}$ for $48 \mathrm{~h}$ in the absence or presence of the test compounds (with the positive control, Efavirenz) [14]. A luciferase assay system (Promega) was used to determine the inhibition rate. The cytotoxicity was measured by the MTT method. SupT1 cells were seeded into a 96-well microtiter plate in the absence or presence of the test compounds (positive control, Efavirenz) in triplicate and incubated at $37.8^{\circ} \mathrm{C}$ in a humid atmosphere of $5 \% \mathrm{CO}_{2}$. After a 4-day incubation, cell viability was measured by the MTT method. Purities of all of the tested compounds were $>95 \%$, as detected by HPLC-ELSD. Efavirenz were obtained from NIH-AIDS Research and Reference Reagent Program with a purity of $>98 \%$ (HPLC).

\section{Supporting information}

NMR spectra of 1-15 are available as Supporting Information.

\section{Acknowledgements}

Thanks for the financial support from the National Natural Science Foundation of China (NSFC) No. 31170041 and National Infrastructure of Microbial Resources (No. NIMR-2015-3). Thanks to Miss. Meifeng $\mathrm{Xu}$ in the National Center of Biomedical Analysis (NCBA) for the measurements of the NMR spectra.

\section{Conflict of Interest}

There are no conflicts of interest for all authors.

\section{References}

[1] Li HT, Kang LP, Guo BL, Zhang ZL, Guan YH, Pang X, Peng CZ, Ma BP, Zhang LX. Original plant identification of Dai nationality herb "Daibaijie". Chin J Chin Mater Med 2014; 39: 1525-1529

[2] Pang X, Kang LP, Yu HS, Zhao Y, Han LF, Zhang J, Xiong CQ, Zhang LX, Yu LY, Ma BP. New polyoxypregnane glycosides from the roots of Marsdenia tenacissima. Steroids 2015; 93: 68-76

[3] Liang XW, Wang CC. [Analysis of the relation of clearing heat and expelling miasma medicine and antivirus medicine]. J Liaoning Univ Tradit Chin Med 2009; 11: 28-29

[4] Huang XD, Liu T, Wang S. Two new polyoxypregnane glycosides from Marsdenia tenacissima. Helv Chim Acta 2009; 92: 2111-2117

[5] Ma BX, Fang TZ, Ma K, Ni J, Wu H, Ding WP, Jiang C. Novel saponins hainaneosides A and B isolated from Marsdenia hainanensis. J Nat Prod 1997; 60: 134-138

[6] Li QF, Wang XL, Ding LS, Zhang C. Polyoxypregnanes from the stems of Marsdenia tenacissima. Chin Chem Lett 2007; 18: 831-834

[7] Liu J, Yu ZB, Ye YH, Zhou YW. A new $C_{21}$ steroid glycoside from Marsdenia tenacissima. Chin Chem Lett 2008; 19: 444-446

[8] Wang XL, Peng SL, Ding LS. Further polyoxypregnane glycosides from Marsdenia tenacissima. J Asian Nat Prod Res 2010; 12: 654-661

[9] Deng J, Liao ZX, Chen DF. Marsdenosides A-H, polyoxypregnane glycosides from Marsdenia tenacissima. Phytochemistry 2005; 66: 1040-1051

[10] Deng J, Liao ZX, Chen DF. Two new $C_{21}$ steroids from Marsdenia tenacissima. Chin Chem Lett 2005; 16: 487-490

[11] Wang XL, Li QF, Yu KB, Peng SL, Zhou Y, Ding LS. Four new pregnane glycosides from the stems of Marsdenia tenacissima. Helv Chim Acta 2006; 89: $2738-2744$

[12] Umehara K, Endoh M, Miyase T, Kuroyanagi M, Ueno A. Studies on differentiation inducers. IV. Pregnane derivatives from condurango cortex. Chem Pharm Bull (Tokyo) 1994; 42: 611-616

[13] Sahu N, Panda N, Mandal N, Banerjee S, Koike K, Nikaido T. Polyoxypregnane glycosides from the flowers of Dregea volubilis. Phytochemistry 2002; 61: 383-388

[14] Zhang Q, Liu ZL, Mi ZY, Li XY, jia PP, Zhou JM, Yin X, You XF, Yu LY, Guo F, Ma J, Liang C, Cen S. High-throughput assay to identify inhibitors of Vpumediated down-regulation of cell surface BST-2. Antiviral Res 2011; 91 : 321-329 